\title{
Incineration Fly Ash and Its Treatment to Possible Utilization: A Review
}

\author{
Altaf Hussain Kanhar, Shaoqing Chen and Fei Wang * \\ State Key Laboratory of Clean Energy Utilization, Zhejiang University, Hangzhou 310027, China; \\ kanharaltaf@zju.edu.cn (A.H.K.); sqchen1987@zju.edu.cn (S.C.) \\ * Correspondence: wangfei@zju.edu.cn; Tel.: +86-571-87952628; Fax: +86-571-87952438
}

Received: 29 October 2020; Accepted: 9 December 2020; Published: 17 December 2020

\begin{abstract}
Incineration has gained popularity over landfill as a key solution for the reduction of massively increasing volumes of municipal solid waste (MSW) generation worldwide and in particular China. However, it is not the end solution. The disposal of the incineration residues, which are enriched with a wide range of heavy metals and soluble salts, has become a challenge for the environmental managers. The aim of this study was to review the increasing urbanization and its repercussion on waste generation in China; waste management options were compared for possible environmentally friendly considerations. Treatment techniques of incineration fly ash were discussed to determine the effectiveness of obtaining environmentally stable material, and, finally, possible applications of incineration fly ash for utilization were discussed based on identifying the processing suitability, performance and environmental impact of incineration fly ash for its applications.
\end{abstract}

Keywords: municipal solid waste; incineration; fly ash; urbanization; heavy metals; treatment techniques

\section{Introduction}

In 2016, around 2.01 billion tons of solid waste was generated worldwide. With increasing population, urban expansion and industrialization, the annual waste generation is expected to increase by $70 \%$ in the coming two decades [1]. Chinese urban expansion is increasing year by year and so is the generation of municipal solid waste. With around $18.5 \%$ of the world's total population, China ranks on top for Municipal Solid Waste (MSW) generation. Landfill, being the most widely used solid waste disposal option, is confronting numerous challenges attributed to land restriction, contaminations and legislations worldwide. How to dispose of millions of tons of MSW is becoming the biggest issue for environmental managers [2,3]; alternatively, municipal solid waste disposal is expected to make developments in improved landfill bioreactors, composting and thermal processes. Amongst these, incineration is widely accepted because of its small land footprint, huge mass and volume reduction, and, additionally, energy can be recovered in the form of heat and electricity [4-6]. MSW incineration helps to achieve a 70-90\% reduction in mass and volume [7,8]. In comparison to sanitary landfills, incineration is more acceptable and valued in developed and under developing countries such as China because of its huge population, increasing land prices and increasing environmental awareness in people.

However, MSW incineration confronts the problem of how to deal with the considerable amount of incineration residues ( $\sim 30 \%$ by mass), which mainly consist of bottom ash and fly ash. According to the International Ash Working Group (IAWG), fly ash is defined as the ash that is discharged from the combustion chamber without the addition of any type of sorbents, such as the ash from a super heater, economizer and air preheater. In the study of municipal solid waste incineration (MSWI), fly ash is referred to the air pollution control (APC) residues that include the ash trapped by electrostatic precipitators and bag filters. It is estimated that the amount of fly ash produced accounts for 
approximately $3-10 \%$ of incineration waste [9]. The fly ash possesses a higher amount of heavy metal concentrations than that of bottom ash, which is resulted by the chemical partitioning of heavy metals accelerated by the temperature and the presence of chlorine, originated from the types of wastes incinerated (food, PVC, etc.) [10]. Therefore, various countries, such as the USA, France, Canada, Japan, Italy, Germany, Sweden, etc., have introduced policies for the proper control and management of MSWI fly ash. In 2016, the Chinese government also included MSWI fly ash in the National Hazardous Waste List. The law issued by the National Environmental Protection Standards of the People's Republic of China (HJ 1134-2020) in August-2020 will prevent and control environmental pollution, improve the quality of the ecological environment, standardize and guide the environmental management of MSW incineration fly ash. According to this law, the regulations specify the overall requirements for the pollution control of MSW incineration fly ash, collection, storage, transportation, treatment and disposal. Which means fly ash in China cannot be disposed of without prior treatment [11-14].

Therefore, various treatment techniques are exercised to eliminate the hazardous and toxic content in MSWI fly ash. The characteristics of MSW incineration fly ash may serve as a key tool to choose the best option for treatment $[11,12,15]$. At present, there are lots of studies carried out on the stabilization/removal of heavy metals from MSW incineration fly ash. The treatment techniques can be classified as separation techniques, stabilization/solidification and thermal treatments. The treatment techniques are differentiated mainly on the characteristics of process product than that of the process [16]. The separation techniques firstly separate the heavy metals from fly ash using a chemical reagent, biological reagent or electrodialysis method. The cement solidification refers to the use of fly ash as an additive to the concrete production process. During the production process, the heavy metal components in fly ash are fixed in the concrete product. This technique not only realizes fly ash as a resource material for the production of cement, but also facilitates the harmless treatment of fly ash, whereas chemical stabilization involves different organic chelating reagents or inorganic chemicals to reduce the leaching of heavy metals in fly ash to facilitate subsequent disposal. The thermal treatment is further divided into sintering, melting, vitrification and thermochemical treatment. The treated fly ash is then required to be either disposed of or utilized in possible applications such as construction material, geotechnical applications, agriculture, etc. In each application for fly ash reuse, recycle and recover comes advantages, for example, conservation of natural resources, elimination of waste and availability of zero-cost raw materials.

To date, several research studies and reviews have been published for MSW generation and management [11-13,17-20], treatment techniques of incineration residues [21-27], social factors [25-28], demographics [28-31], economics [28,30,32,33] and on policies [34]. However, little work has been done to understand and investigate the rapid urbanization and its consequences on waste management. The occurrences of heavy metals, treatment techniques and existing practices related to the reuse of MSW incineration fly ash to identify potential application in China. Therefore, the aim of this study was to review the increasing urbanization and its repercussion on waste generation in China; waste management options were compared for possible environmentally friendly considerations. Treatment techniques of incineration fly ash were investigated to determine effectiveness in obtaining environmentally stable material, and, finally, possible applications of incineration fly ash for utilization were discussed based on identifying the processing suitability, performance and environmental impact of incineration fly ash for its applications.

\section{Urbanization and Waste Management in China}

\subsection{Situation in China}

China is a developing country. Over the past three decades, the world has witnessed unparalleled growth in Chinese urban settlement and economy. China's tremendous development has not only brought economic incline, stability and improved living standards but has also attracted huge environmental concerns for the generation of uncontrolled waste. China is in fact the only country 
in the world that has mass migration within the country. The urban population proportion in 1996 was 207.4 million, making up to $17 \%$ of total population, but, according to 2019 statistics, the urban population in China reached around 874.4 million, which holds $60.4 \%$ of total population of China. In China urban areas are highly correlated with solid waste generation of all cities with respect to their area and amount of waste generated. Because of this rapid urbanization and increasing life standards, China ranks top in the growth of MSW generation. Thus, uncontrolled increase in the volume of solid waste generation is becoming a bottleneck issue. A number of cities in China are struggling to cope with the serious crisis of solid waste generation and its management because of the increasing land prices and scarcity of land available for landfilling. The statistics presented during the year 2017 MSW generation in China surpassed 220.6 million tons per year, and the collected and disposed amount was 198 million tons. The increase in waste generation is predicted to increase $3.6 \%$, and the disposal and collection rate is expected to increase $8.8 \%$ per year. It is estimated that the urban population in China will become 947 million and it will account for $65.9 \%$ of total population in 2025, and MSW generation will reach 325 million and 480 million tons in 2020 and 2025, respectively [35-40]. Therefore, research studies should be carried out to quantify the impact of urbanization on the composition of municipal solid waste, which has so far received little attention in China.

\subsection{Waste Management}

In order to handle and create awareness for waste management Chinese government has initiated some measures to encourage the development of safe MSW disposal. For example, the introduction of "eco-cities" or "environmental protection model cities" has gathered huge positive turnout [12]. Every city wants to win this title, but, to secure the title, cities need to achieve $85 \%$ to $90 \%$ safe MSW disposal. The growth of MSW management industry is gaining continuous support and financial assistance under the national environmental investment projects: USD 115 billion was allocated for the 12th five-year plan (from 2011 to 2015) and around USD 150 billion was invested for the 13th five-year plan (from 2016 to 2020) [41-43]. Such measures not only attract safe disposal and waste minimization but also play a positive role in environmental awareness. Although waste management in China is improving, it is still a challenging task, and to achieve required results needs more time and innovation in waste management [44,45]. According to [15], in Germany, all landfill sites for untreated municipal solid waste were completely shut down during 2005; however, in China, more than $57 \%$ of waste disposal is still accounted for by landfill. MSW management in China is also increasingly focusing on the recycling of wastes to avoid environmental pollution caused by the growing amounts of MSW. The Chinese government has also set a target of disposing nearly a third of the country's waste with waste-to-energy plants by 2030 .

\subsection{Recycling Valuable Waste Fractions}

With the continuous expansion of urban areas and industrialization, China is confronting several challenges, including resource depletion and environmental pollution. Furthermore, the growing amounts of municipal solid waste are becoming problematic owing to the limited availability of land for new landfill sites. Thus, its necessary to encourage the utilization of recyclable waste, which can simultaneously cover the issues of limited land for landfill sites, natural resource depletion and environmental pollution. Recyclable wastes are wastes generated from domestic sources and industries, but they can be recycled after adequate processing and sorting. The main examples involve metal waste, paper waste, glass waste, plastic waste, tires, electrical and electronic equipment waste and home appliances. The process of recyclable waste management is still in its infancy in China compared to other developed countries, such as Japan [46,47], which has achieved a great deal in establishing an urban waste recycling system. In this regard, the Chinese government is effectively promoting the recycling of recyclable wastes, multiple documents have been released for promoting and encouraging the urban waste recycling and source separation in China [48-53]. In 2006, the Ministry of Commerce (MOC) of China introduced a plan of recyclable waste recycling in 26 cities on a pilot scale, which then 
expanded from 29 cities to 35 cities from 2009 to 2012 [49-51]. Most of the pilot projects of recyclable waste recycling systems are developed in eastern parts of China [54]. The aim of developing pilot projects was to create awareness at a local government level to gain experiences from recyclable waste recycling pilot projects and then implement it on a local level based on the local realities.

In last decade, considerable progress has been seen in recycling valuable waste fractions in China. According to the statistics presented in 2016 by [55], recyclable wastes reached around 246 million tons. The recycling of most common wastes, such as plastic waste, paper waste, automobile waste, steel waste and electrical and electronic equipment waste has been improved. For example, in China, waste paper is regarded as the most common secondary resource, and its recycling rate increased from $27.5 \%$ in 2001 to $46.7 \%$ in 2015 [55]. In comparison, the recycling rate of plastic waste was lower, increasing from $20 \%$ (2001) to 30\% (2015), and around 19.7\% was observed for electrical and electronic equipment waste in 2015 [55].

Although the recycling of waste is increasing day by day in China, there are still some challenges to face, for example, insufficient municipal solid waste separation, MSW being the dominant waste, which has a high proportion of organic components, and the separation of domestic waste is also low [56]. These problems can be well handled by (1) the creation of proper recycling platforms, (2) encouraging sufficient MSW separation, (3) establishing market with effective government administration and (4) the introduction of new policies which can encourage and educate the common man about waste and its importance.

\subsection{Waste Disposal Options}

The waste disposal options in China are mainly landfill and incineration [57-60]. The other disposal options account for a very small percentage, as can be seen in Table 1, which gives an overview of MSW generation and disposal in China between 2003 and 2016. An obvious increase in the amount of waste incinerated can be seen from 2.49\% to $35.25 \%$ from 2003 to 2016.

Old disposal options seem easy to handle but they carry huge problems. The MSWI residues can cause leachate enriched with salts and heavy metals, which is the main drawback for the utilization of MSWI residues. Therefore, to compare and determine waste disposal options, a comparison of disposal options can be seen in Table 2, which defines the role of each disposal option based on factors such as scale, site feasibility and its dependence on technology, the status of final product and its marketing, the main causes of pollution (air, soil and ground water), the measures taken to protect the environment and finally the current statuses of development of each disposal options, which were presented and analyzed based on the environmentally friendly considerations. Based on the comparison of waste disposal options, it can be stated that these waste options are less likely to be adopted in a modern world where increasing environmental awareness and stringent legislation rejects any such step, which endangers the environment. The Chinese government is struggling to seek out more effective ways to dispose of MSW. As in Singapore and Japan, the ratio of waste incineration is more than $90 \%$, which is not only minimizing waste burden but also generating energy [60,61]. In China, compared to other waste management and disposal options, incineration serves the management of MSW very well because it helps in the reduction of mass, volume and generation of energy. 
Table 1. MSW generation and disposal in China between 2003 and 2016 (data from National Bureau of Statistics (NBS, 2017).

\begin{tabular}{|c|c|c|c|c|c|c|c|c|c|c|}
\hline \multirow[b]{2}{*}{ Year } & \multirow{2}{*}{$\begin{array}{l}\text { Collected \& } \\
\text { Transported } \\
\text { MSW (M/T) }\end{array}$} & \multicolumn{4}{|c|}{ Number of MSW Disposal Facilities } & \multicolumn{4}{|c|}{ MSW Disposed (Tons) } & \multirow{2}{*}{$\begin{array}{c}\text { Share of } \\
\text { Incineration in } \\
\text { MSW Disposal }(\%\end{array}$} \\
\hline & & $\begin{array}{c}\text { Total } \\
\text { Number }\end{array}$ & Landfills & $\begin{array}{l}\text { Incineration } \\
\text { Facilities }\end{array}$ & Others & $\begin{array}{c}\text { Total } \\
\text { Volume }\end{array}$ & Landfilled & Incinerated & $\begin{array}{l}\text { Other } \\
\text { Means }\end{array}$ & \\
\hline 2003 & 148.59 & 575 & 457 & 47 & NA & 7544.7 & 6404 & 369.9 & NA & 2.49 \\
\hline 2004 & 155.17 & 559 & 444 & 54 & NA & 8088.7 & 6888.9 & 449 & NA & 2.90 \\
\hline 2005 & 155.82 & 471 & 356 & 67 & NA & 8051.1 & 6857.1 & 791 & NA & 5.08 \\
\hline 2006 & 148.44 & 419 & 324 & 69 & NA & 7872.6 & 6408.2 & 1137.6 & NA & 7.67 \\
\hline 2007 & 152.16 & 460 & 366 & 66 & NA & 9437.7 & 7632.7 & 1435.1 & NA & 9.43 \\
\hline 2008 & 154.45 & 509 & 407 & 74 & NA & $10,306.6$ & 8424 & 1569.7 & NA & 10.17 \\
\hline 2009 & 157.39 & 567 & 447 & 93 & NA & $11,232.3$ & 8898.6 & 2022 & NA & 12.85 \\
\hline 2010 & 158.06 & 628 & 498 & 104 & NA & $12,317.8$ & 9598.3 & 2316.7 & NA & 14.66 \\
\hline 2011 & 164.06 & 677 & 547 & 109 & 21 & $13,089.6$ & $10,063.7$ & 2599.3 & NA & 15.85 \\
\hline 2012 & 170.82 & 701 & 540 & 138 & 23 & $14,489.5$ & $10,512.5$ & 3584.1 & 393 & 20.98 \\
\hline 2013 & 172.45 & 765 & 580 & 166 & 19 & 15,394 & $10,492.7$ & 4633.7 & 267.6 & 26.88 \\
\hline 2014 & 178.65 & 818 & 604 & 188 & 26 & $16,393.7$ & $10,744.3$ & 5329.9 & 319.6 & 29.84 \\
\hline 2015 & 191.46 & 890 & 640 & 220 & 30 & 18,013 & 11,483 & 6175.5 & 354.4 & 32.26 \\
\hline 2016 & 203.65 & 940 & 657 & 249 & 34 & $19,673.8$ & $11,866.4$ & 7178.4 & 428.9 & 35.25 \\
\hline Total & 2310.5 & 8979 & 6867 & 1644 & 153 & $171,905.1$ & $126,274.4$ & $39,591.9$ & 1763.5 & 17.14 \\
\hline
\end{tabular}


Table 2. Comparison of waste disposal options.

\begin{tabular}{|c|c|c|c|}
\hline Consideration & Incineration & Landfill & Composting \\
\hline Scale & 150 to $1200 \mathrm{t} / \mathrm{d}$ & Large scale & $\begin{array}{l}\text { 100-200 for static and } \\
250-500 \text { for dynamic }\end{array}$ \\
\hline Site feasibility & $\begin{array}{l}\text { Siting is sensitive, } \\
\text { transportation distance } \\
\text { should short, possibility } \\
\text { of siting it near to } \\
\text { downtown }\end{array}$ & $\begin{array}{l}\text { Very hard, high land } \\
\text { prices, away from urban } \\
\text { areas, transportation } \\
\text { within } 30 \mathrm{~km} \text { of distance. }\end{array}$ & $\begin{array}{c}\text { Easy, away from } \\
\text { populated areas, short } \\
\text { distance }\end{array}$ \\
\hline $\begin{array}{l}\text { Dependability on } \\
\text { technology }\end{array}$ & $\begin{array}{c}\text { Dependable, accepted } \\
\text { worldwide, still growing }\end{array}$ & $\begin{array}{l}\text { Old technique, } \\
\text { dependable }\end{array}$ & Acceptable \\
\hline Product and its market & Generation of energy & $\begin{array}{l}\text { Generation of biogas, } \\
\text { source for power } \\
\text { generation }\end{array}$ & $\begin{array}{l}\text { Single product with low } \\
\text { market acceptability }\end{array}$ \\
\hline Final product & $\begin{array}{l}\text { Demands treatment prior } \\
\text { to disposal or reuse }\end{array}$ & Disposal option itself & $\begin{array}{l}\text { Demands landfill } \\
\text { disposal }\end{array}$ \\
\hline Air pollution & $\begin{array}{l}\text { Strictly demands to } \\
\text { control flow gases, heavy } \\
\text { metals, salts and dioxins }\end{array}$ & $\begin{array}{c}\text { Chance of air pollution if } \\
\text { left uncovered }\end{array}$ & $\begin{array}{l}\text { Odor, requires odor } \\
\text { prevention }\end{array}$ \\
\hline Soil pollution & $\begin{array}{l}\text { Prior site selection for } \\
\text { ash pile/stacking }\end{array}$ & Restricted to landfill site & $\begin{array}{l}\mathrm{pH} \text { and content of heavy } \\
\text { metals should be } \\
\text { controlled }\end{array}$ \\
\hline Ground water pollution & $\begin{array}{c}\text { Dependent on } \\
\text { construction of landfill }\end{array}$ & $\begin{array}{l}\text { Leaked bottom can } \\
\text { pollute within } 3 \mathrm{~km} \\
\text { radius of landfill sites }\end{array}$ & Low chances \\
\hline $\begin{array}{c}\text { Environmental } \\
\text { protection measures }\end{array}$ & $\begin{array}{l}\text { Residue disposal, waste } \\
\text { mass loss, No noise } \\
\text { pollution, odor control } \\
\text { and prevention. }\end{array}$ & $\begin{array}{l}\text { Bottom leak-proof but it } \\
\text { requires huge } \\
\text { investments }\end{array}$ & $\begin{array}{l}\text { Requires high } \\
\text { production cost }\end{array}$ \\
\hline $\begin{array}{l}\text { Development and } \\
\text { current status }\end{array}$ & $\begin{array}{l}\text { Increasing and gaining } \\
\text { popularity }\end{array}$ & $\begin{array}{l}\text { Numbers are getting } \\
\text { lower and lower. } \\
\text { Restricted in many } \\
\text { countries }\end{array}$ & Limited \\
\hline
\end{tabular}

\subsection{Waste Incineration}

In China, MSW incineration technology was initiated during the 1980s and underwent a rapid development and acceptance in the 1990s. According to statistics, the share of MSW incineration has gone bigger from $2.49 \%$ in 2003 to $35.25 \%$ in 2016 . The MSW generation and disposal in selected provinces of China can be seen in Table 3, which discloses the operational MSW incineration plants in China. It is reported that during 2016 China had 299 incineration plants, which handled 280,000 tons of waste per day in different towns and cities. It is predicted that by the end of the "13th 5-year plan" in 2020, the proportion of waste incineration will increase and the number of incineration plants will reach to 400 . So, the majority of MSW incinerators are distributed in eastern and coastal parts of China. Some developed economies and higher population density provinces, such as Guangdong, Zhejiang and Jiangsu, share nearly half of the incinerators in China [10], as shown in Table 3. Guangdong, being the most populous province, collects and transports around 23 million tons, of which around 7.86 million tons are incinerated, whereas, with a huge number of incinerators, up to $60 \%$ of MSW is incinerated in Jiangsu and Zhejiang province alone. In central and western parts of China, incinerators are found only in the provincial capitals, probably because of lower economies than those eastern and coastal parts of China.

With the steady increase in combustion in China, it is also important to ensure that the environment is protected from direct emissions into the atmosphere. Since the incineration residues consist of particulate matter collected through different air pollution control devices, mostly characterized by higher concentrations of salts, heavy metals, etc., these characteristics hinder the use of subsequent applications and demand treatment to make it environmentally friendly. 
Table 3. MSW generation and disposal in selected provinces of China in 2016 (data from National Bureau of Statistics (NBS, 2017).

\begin{tabular}{|c|c|c|c|c|c|c|c|}
\hline Province & $\begin{array}{l}\text { Collected and } \\
\text { Transported MSW } \\
\text { (Million Tons) }\end{array}$ & $\begin{array}{c}\text { No. of } \\
\text { Incinerators }\end{array}$ & $\begin{array}{l}\text { MSW Landfilled } \\
\text { (Million Tons) }\end{array}$ & $\begin{array}{l}\text { MSW Incinerated } \\
\text { (Million Tons) }\end{array}$ & $\begin{array}{l}\text { Landfill Capacity } \\
\text { (Tons/d) }\end{array}$ & $\begin{array}{c}\text { Incineration } \\
\text { Capacity (Tons/d) }\end{array}$ & $\begin{array}{l}\text { Share of Incineration } \\
\text { in MSW Disposal (\%) }\end{array}$ \\
\hline Beijing & 8.73 & 7 & 4.73 & 2.73 & $9.14 \times 10^{-3}$ & $1.04 \times 10^{-4}$ & 31.23 \\
\hline Shanghai & 6.29 & 7 & 3.30 & 2.73 & $1.12 \times 10^{-4}$ & $1.13 \times 10^{-4}$ & 43.36 \\
\hline Jiangsu & 15.6 & 30 & 4.52 & 11.1 & $2.23 \times 10^{-4}$ & $3.31 \times 10^{-4}$ & 71.00 \\
\hline Zhejiang & 14.3 & 35 & 5.99 & 8.35 & $1.36 \times 10^{-4}$ & $3.45 \times 10^{-4}$ & 58.24 \\
\hline Shandong & 14.7 & 24 & 7.05 & 7.08 & $2.01 \times 10^{-4}$ & $2.06 \times 10^{-4}$ & 48.25 \\
\hline Hubei & 8.80 & 12 & 4.45 & 3.75 & $1.13 \times 10^{-4}$ & $1.25 \times 10^{-4}$ & 42.56 \\
\hline Guangdong & 23.9 & 24 & 14.8 & 7.86 & $4.00 \times 10^{-4}$ & $3.00 \times 10^{-4}$ & 32.87 \\
\hline Chongqing & 4.64 & 3 & 2.99 & 1.95 & $7.35 \times 10^{-3}$ & $4.40 \times 10^{-3}$ & 41.93 \\
\hline Sichuan & 8.87 & 14 & 5.12 & 3.62 & $1.24 \times 10^{-4}$ & $1.21 \times 10^{-4}$ & 40.81 \\
\hline Guizhou & 2.94 & 4 & 2.38 & 0.404 & $6.89 \times 10^{-3}$ & $2.40 \times 10^{-3}$ & 13.74 \\
\hline
\end{tabular}




\section{Occurrence of Heavy Metals in MSW Incineration Ash}

The characterization and composition of incineration ash varies over time and from region to region and country to country due to the difference in waste management/treatment practices [62]. In China, composition of MSW is extremely non-homogenous and variations may be because of living conditions, geographical distance, industrialization and urbanization [63-65]. Incineration of MSW in China faces serious technical challenges owing to the low calorific values. MSW in developed countries such as the USA, Japan and South Korea has higher heating values, ranging from 8400 to $17,000 \mathrm{~kJ} / \mathrm{kg}$, due to the presence of more combustible components and lower moisture contents. According to [64-66], MSW in China is dominated by food waste, and its moisture content is near to $50 \%$. In contrast to this, the moisture content is around 20 to $30 \%$ in Europe and North America. In China, the waste management is lacking in implementing an appropriate policy for the recovery of resources from waste, for example, rubbish collectors collect the majority of combustible materials such as plastic and paper. Therefore, to handle this issue of low calorific values, the uses of supplementary fuels are often observed in China, hence the incineration residues emerge with more challenges, as supplementary fuels also contain heavy metals.

The heavy metal contents in fly ash are determined by the source characteristics of MSW, incineration conditions and air pollution control (APC) devices installed. The similar combustion technology and varying APC devices and difference in the source of MSW generated in different parts of China may also be the cause of variations in the content of heavy metals [10]. Fly ash is typically collected in various types of cyclones, filters and electrostatic precipitator. The wastes carried over by flu gases from combustion chamber are categorized in different groups, as shown in Figure 1 by [16,25], such as fly ash and APC residues.

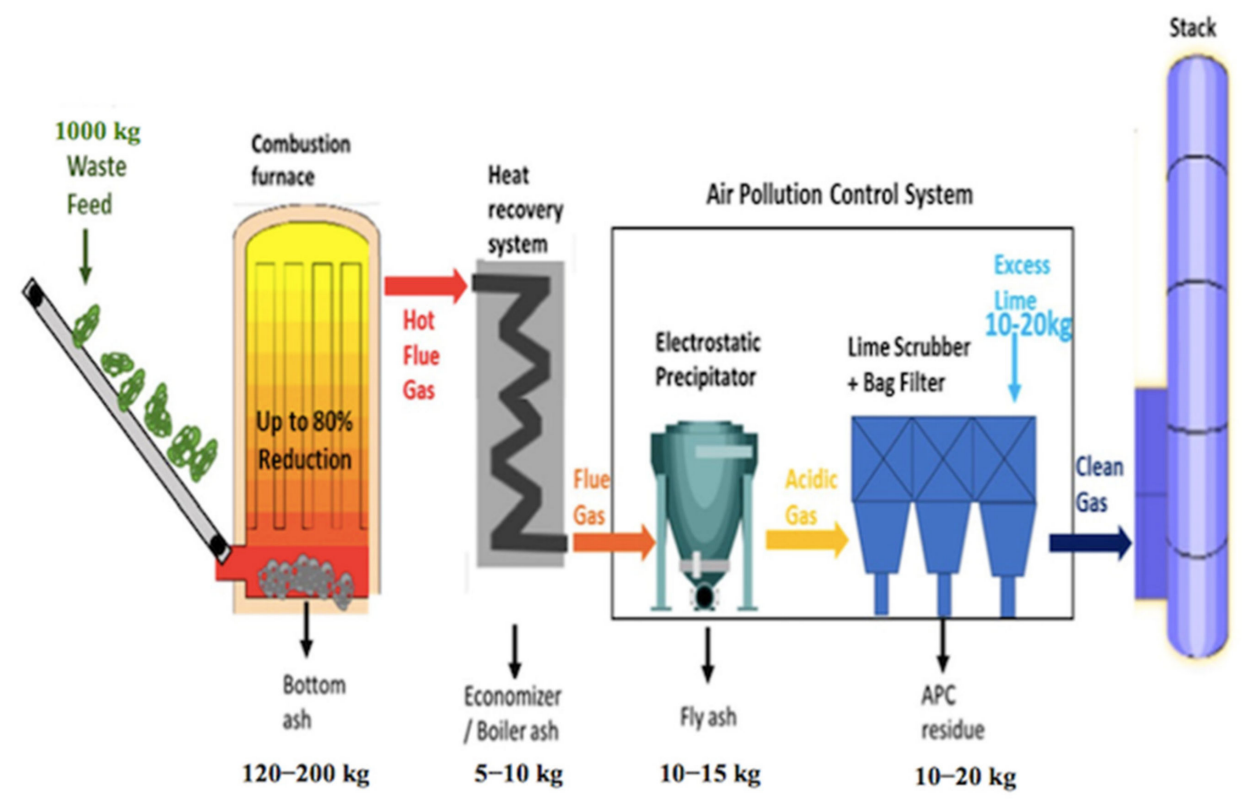

Figure 1. The mass fraction of residues in MSW incineration.

According to [16,67], these residues may differ in their composition and leaching behavior. Some authors $[25,68,69]$ have considered fly ash (FA) and APC as a similar waste with similar waste content. Contrastingly, ref. $[16,67]$ have shown the probability of managing FA and APC individually. Until now, there has been such consensus on the management of these residues.

The emission of heavy metals (HMs) during the incineration of MSW is affected because of several reasons, such as the type of incinerator, sources of MSW, combustion temperature and mainly the composition of MSW [70,71]. Later on, the distribution of HMs in BA and FA are mutually resolved on the basis of physiochemical properties of HMs and their compounds. 
The content of heavy metals is found higher in fly ash than that of bottom ash, as can be seen in Tables 4 and 5, which enlist the amount of heavy metals for fly ash and bottom ash. The composition of incineration ash depends strongly upon the kind of waste and the share of other waste (e.g., paper, plastic, metals, food waste) present in the waste. Paper and plastic are the source of generating Cd, $\mathrm{Cr}$ and $\mathrm{Pb}$ in southern parts of China; the abundance of paper and plastic in MSW is in higher quantities compared to other parts of China.

Table 4. Heavy metal content (mg/kg) in MSWI fly ash (FA).

\begin{tabular}{ccccc}
\hline Metals Ref: & Fly Ash [72] & Fly Ash [73] & Fly Ash [74] & Fly Ash [75] \\
\hline $\mathrm{Ag}$ & $31-95$ & ND-700 & N/A & N/A \\
$\mathrm{As}$ & $31-95$ & $15-751$ & 93 & N/A \\
$\mathrm{Ba}$ & $920-1800$ & $88-9001$ & 4300 & 539 \\
$\mathrm{Cd}$ & $250-450$ & $5-2211$ & 470 & 95 \\
$\mathrm{Co}$ & $29-69$ & $2.3-1671$ & $\mathrm{~N} / \mathrm{A}$ & 14 \\
$\mathrm{Cr}$ & $140-530$ & $21-1901$ & 863 & 72 \\
$\mathrm{Cu}$ & $860-1400$ & $187-2381$ & 1300 & 570 \\
$\mathrm{Hg}$ & $0.8-7$ & $0.9-73$ & $\mathrm{~N} / \mathrm{A}$ & N/A \\
$\mathrm{Mn}$ & $0.8-1.7$ & $171-8500$ & 1600 & 309 \\
$\mathrm{Ni}$ & $95-240$ & $10-1970$ & 124 & 22 \\
$\mathrm{~Pb}$ & $7400-19,000$ & $200-2600$ & 10,900 & 2000 \\
$\mathrm{Se}$ & $6.1-31$ & $0.48-16$ & 41 & $\mathrm{~N} / \mathrm{A}$ \\
$\mathrm{Zn}$ & $19,000-41,000$ & $2800-152,000$ & 25,800 & 6288 \\
$\mathrm{Sn}$ & $1400-1900$ & N/A & N/A & N/A \\
$\mathrm{Sr}$ & $80-250$ & N/A & 433 & 151 \\
$\mathrm{~V}$ & $32-150$ & N/A & 37 & N/A \\
\hline
\end{tabular}

Table 5. Heavy metal content (mg/kg) MSWI bottom ash (BA).

\begin{tabular}{ccccc}
\hline Metals Ref: & Bottom Ash [76] & Bottom Ash [73] & Bottom Ash [77] & Bottom Ash [78] \\
\hline $\mathrm{Ag}$ & $4.1-14$ & $2-38$ & $8.5-10.7$ & N/A \\
$\mathrm{As}$ & $19-80$ & $1.3-45$ & $209-227$ & 13 \\
$\mathrm{Ba}$ & $900-2700$ & $47-2000$ & $1104-1166$ & N/A \\
$\mathrm{Cd}$ & $1.4-40$ & $0.3-61$ & $6.8-7.8$ & 3 \\
$\mathrm{Co}$ & $<10-40$ & $22-706$ & $49.6-53.1$ & $\mathrm{~N} / \mathrm{A}$ \\
$\mathrm{Cr}$ & $230-600$ & $13-1400$ & $323-439$ & 900 \\
$\mathrm{Cu}$ & $900-4800$ & $80-10,700$ & $4139-4474$ & 500 \\
$\mathrm{Hg}$ & $<0.01-3$ & $0.003-2$ & N/A & 2.6 \\
$\mathrm{Mn}$ & $<0.7-1.7$ & $50-3100$ & $869-894$ & 280 \\
$\mathrm{Ni}$ & $60-190$ & $9-430$ & $216-242$ & 180 \\
$\mathrm{~Pb}$ & $1300-5400$ & $98-6500$ & $2474-2807$ & 2700 \\
$\mathrm{Se}$ & $0.6-8$ & ND-3.4 & $230-265$ & N/A \\
$\mathrm{Zn}$ & $1800-5400$ & $200-12,400$ & $4261-4535$ & 600 \\
$\mathrm{Sn}$ & $<100-1300$ & N/A & N/A & 960 \\
$\mathrm{Sr}$ & $170-350$ & N/A & N/A & N/A \\
$\mathrm{V}$ & $36-90$ & N/A & N/A & N/A \\
\hline
\end{tabular}

The waste from paper may carry higher amounts of fillers such as lime and kaolin. Waste from the food may contain s considerable quantity of $\mathrm{NaCl}$. In some of the big cities of China, the composition of waste is similar to that in Western Europe and comprises a higher share of paper and plastic. China's waste stream is growing faster in paper, plastics and multi-laminates [38]. However, the composition of MSW in China is far different from that of the western industrialized world. The case study by [18] explains the difference on the basis of heavy metal content in FA, BA and APC, and, according to [21], the content of $\mathrm{Zn}$ and $\mathrm{Pb}$ in China is lower than other countries, which can be seen from the Table 6 . This difference may be because of operational and geographical conditions but until now there has been no such relevant information available to justify the differences. However, 
ref. [38] elaborates that the high content of $\mathrm{Zn}$ and $\mathrm{Pb}$ may be because of the abundance of high waste fractions (batteries, colored containers, plastics, ceramics, etc.).

Table 6. Heavy metal $\mathrm{Pb}$ and $\mathrm{Zn}$ content (mg/kg) in MSWI fly ash (FA) and MSWI bottom ash (BA).

\begin{tabular}{cccc}
\hline Country & Pb (FA) & Zn (FA) & Ref: \\
\hline China & $782.6-9901$ & $2088-14,129$ & {$[79,80]$} \\
Japan & 1878 & 8347 & {$[81]$} \\
Korea & $910-3600$ & $5200-8640$ & {$[82,83]$} \\
Denmark & $7400-19,000$ & $19,000-41,000$ & {$[76]$} \\
Germany & 13,600 & 49,100 & {$[84]$} \\
Spain & 5461 & 9382 & {$[85]$} \\
Netherlands & $5300-26,000$ & $9000-70,000$ & {$[86]$} \\
\hline Country & Pb (BA) & Zn (BA) & Ref: \\
\hline China & $647-2223$ & $3378-3979$ & {$[87,88]$} \\
Japan & $140-2700$ & $1500-5000$ & {$[82,89]$} \\
Korea & $750-1000$ & $3100-4405$ & {$[83,90]$} \\
Denmark & $1300-5400$ & $1800-6200$ & {$[76]$} \\
Italy & $1115-1473$ & $4516-21,344$ & {$[91]$} \\
Spain & 2700 & 600 & {$[78]$} \\
Netherlands & $100-13,700$ & $1000-7000$ & {$[86]$} \\
\hline
\end{tabular}

Several researchers have studied and reviewed the BA, FA and APC's data on the basis of their chemical composition. The research on the occurrence of heavy metals in MSW incineration ash is rarely investigated in China; the literature available shows the difference in content because of MSW composition and generation in different parts or regions. The temporal and spatial trends in heavy metal contents of fly ash studied by [10] also agrees with the fact that variations in the content of heavy metals are because of socioeconomic conditions across China. Furthermore, after depicting the temporal trends in the contents of heavy metals in MSW incineration fly ash over the past 15 years, it was concluded that the contents of heavy metals in MSW incineration fly ash could be considered as roughly constant between 2003 and 2017 [10]. The heavy metal content determines not only the choice of treatment option, but also the possible behavior of the ash during landfill or reuse.

\section{Treatment of Incineration Fly Ash}

The presence of heavy metals and soluble salts classifies fly ash as a hazardous material, which requires treatment prior to disposal or utilization. The focus of recent treatment techniques/technologies is to reduce the environmental threat posed by the hazardous content of fly ash. The treatment of incineration fly ash would not only ensure the environmentally friendly applications and economical consideration of incineration fly ash but also serves as the alternate to the existing scare resources. This section summarizes the treatment techniques of fly ash developed in recent years. The treatment techniques/methods and principles of treatment of incineration ash are discussed below in Figure 2.

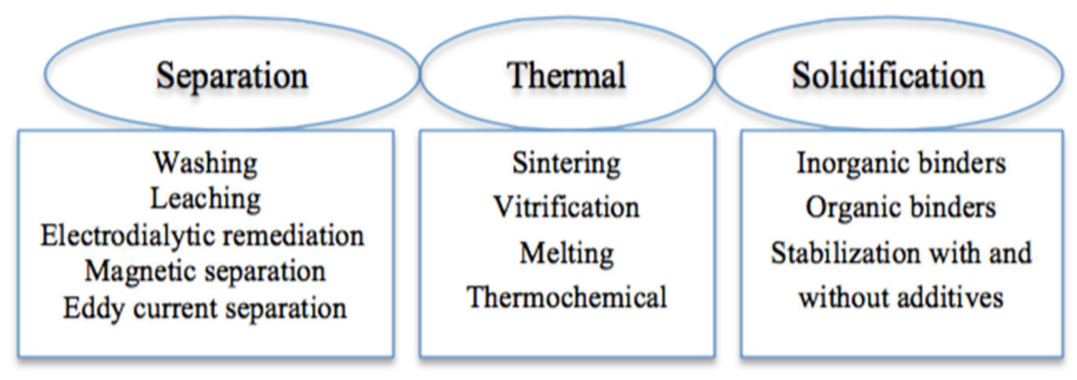

Figure 2. Shows the treatment techniques of incineration ashes. 


\subsection{Separation Process}

Separation processes are mainly used to separate particles with similar chemical and physical properties from the bulk materials.

\subsubsection{Washing}

Washing treatment is aimed to efficiently reduce and eliminate chlorides, alkaline, soluble salts and heavy metals from incineration ash by exercising a liquid solution, commonly water or acid [21,22]. Water washing processes can be carried out in one step or several sequential steps. Several studies have shown that the removal of chloride is very rigorous during the first step and according to [92] lower removal efficiencies were obtained in later steps. In context to that [93-98] supported involvement of water for effective removal of chlorides during washing methods. As per the literature review by [16], water washing can remove up to $90-95 \%$ of the chlorides and the final product is improved in quality for further utilization. Strong concerns were raised by [98] for water washing because of its disadvantage to possible release of heavy metals $(\mathrm{Cu}, \mathrm{Pb}$, and $\mathrm{Zn})$ in the leachates. According to [99], involvement of chemical additives or $\mathrm{pH}$ control may overcome this issue. Acid washing involving sulphuric acid and phosphoric acid has shown good results for removal of heavy metals like $\mathrm{Pb}, \mathrm{Zn}$ and $\mathrm{Cu}$ [99]. Contrastingly, according to [100], $\mathrm{H}_{3} \mathrm{PO}_{4}$ is more effective than sulphuric acid. According to $[95,96,100]$, operational parameters such as liquid-to-solid ratio, stirring speed, temperature and time can play important role in reduction of chlorine content in incineration ash during washing method. For example, higher liquid-to-solid ratios will show better results. So far, no consensus on washing parameters has been found in studies. In general, ref. [21,22,94-96,99-101] have pointed out the drawbacks of washing treatment because larger volumes of produced water need to be treated prior to discharge because of contamination. However, recent legislation issued by the National Environmental Protection Standards of the People's Republic of China (HJ 1134-2020) in August-2020 demands a proper treatment prior to discharging the contaminated water under section GB 8978, which says the wastewater generated during the fly ash treatment process should be returned to the process first for recycling or comprehensive utilization. The wastewater generated during the treatment, if discharged directly to the environment, shall meet the requirements mentioned under section GB 8978-Integrated Wastewater Discharge Standard.

\subsubsection{Leaching}

The leaching process is meant to extract heavy metals from incineration ash and later recover them from the leachate solutions. According to [16,22,102-104], the heavy metal leaching process depends strongly on the kind of extraction solvent, $\mathrm{pH}$ and liquid-to-solid ratio. In a leaching solution, an increase in $\mathrm{pH}$ may hinder the leachability of heavy metals possibly because of the formation of insoluble hydroxides. Whereas chelating agents are independent of $\mathrm{pH}$ [105-107], the study by [105] shows the recovery of heavy metals such as $\mathrm{Zn}, \mathrm{Pb}, \mathrm{Cr}$ and $\mathrm{Cu}$ by using chelating agents. The other investigation by $[107,108]$ compared the efficiencies of EDTA, $\mathrm{HClO}_{4}, \mathrm{HCl}, \mathrm{NH}_{4} \mathrm{Cl}_{1} \mathrm{NH}_{4} \mathrm{NO}_{3}$ and various organic acids with usually used mineral acids and water. According to their investigations, strong mineral acids were effective in the leaching of heavy metals compared to organic acids. In particular, $\mathrm{Cu}$ and $\mathrm{Pb}$ were effectively removed by using EDTA, whereas $\mathrm{NH}_{4} \mathrm{NO}_{3}$ was seen as effective for $\mathrm{Cu}$. The question is how these metals can be recovered during the process. The authors of [21] give an overview of how the treatment reagent affects the leaching behavior.

The biological reagents used for heavy metal extraction are acid-resisting and heavy-metal-resisting strains. After proper culturing, they can extract heavy metals from fly ash within the suitable conditions [109]. There are several strains related to this, such as autotrophic thiobacillus species [110] and heterotrophic Aspergillus niger [111]. While investigating the biological leaching of fly ash by Aspergillus niger, ref. [112] discovered that calcium oxalate precipitate affects bioleaching through the weakening of molecule combination in fly ash, thus facilitating the release of heavy metals. The study 
conducted by [113] using thiobacillus species showed that the effective bioleaching was achieved in the presence of up to $8 \%$ fly ash, within a $\mathrm{pH}$ value less than 4 . The $\mathrm{pH}$, the amount of fly ash and the sulphide content can influence the efficiency of heavy metal extraction from fly ash by bioleaching with thiobacillus species. Considering chemical leaching and bioleaching, ref. [114] showed that both methods could effectively leach $\mathrm{Mg}$ and $\mathrm{Zn}$ (leaching rate $>90 \%$ ), $\mathrm{Al}$ and $\mathrm{Mn}$ (leaching rate $>85 \%$ ), and $\mathrm{Cr}(>65 \%), \mathrm{Ga}(>60 \%)$, and $\mathrm{Ce}(>50 \%)$ from fly ash. The use of chemical reagents led to more effective leaching of $\mathrm{Cu}, \mathrm{Fe}$, and $\mathrm{Ni}$, whereas biological reagents promoted the leaching of $\mathrm{Nd}, \mathrm{Pb}$, and Co. Compared to chemical leaching, bioleaching can reduce the $\mathrm{H}_{2} \mathrm{SO}_{4}$ dosage by half, but requires more processing time.

\subsubsection{FLUWA and FLUREC Process}

Municipal solid waste incineration fly ash contains huge potential for recyclable metals such as $\mathrm{Zn}, \mathrm{Pb}, \mathrm{Cu}$ and $\mathrm{Cd}$. The latest "Environmental Protection Law of the People's Republic of China" and "Law of the People's Republic of China on the Prevention and Control of Environmental Pollution by Solid Waste" under section GB/T 30810 urge proper treatment of fly ash to remove and recover precious metals. Such an initiative for the effective separation and recovery of metals from fly ash was taken in Switzerland in 1997, acidic fly ash leaching (FLUWA process) in 1997, as described in detail by [115] is shown in Figure 3.

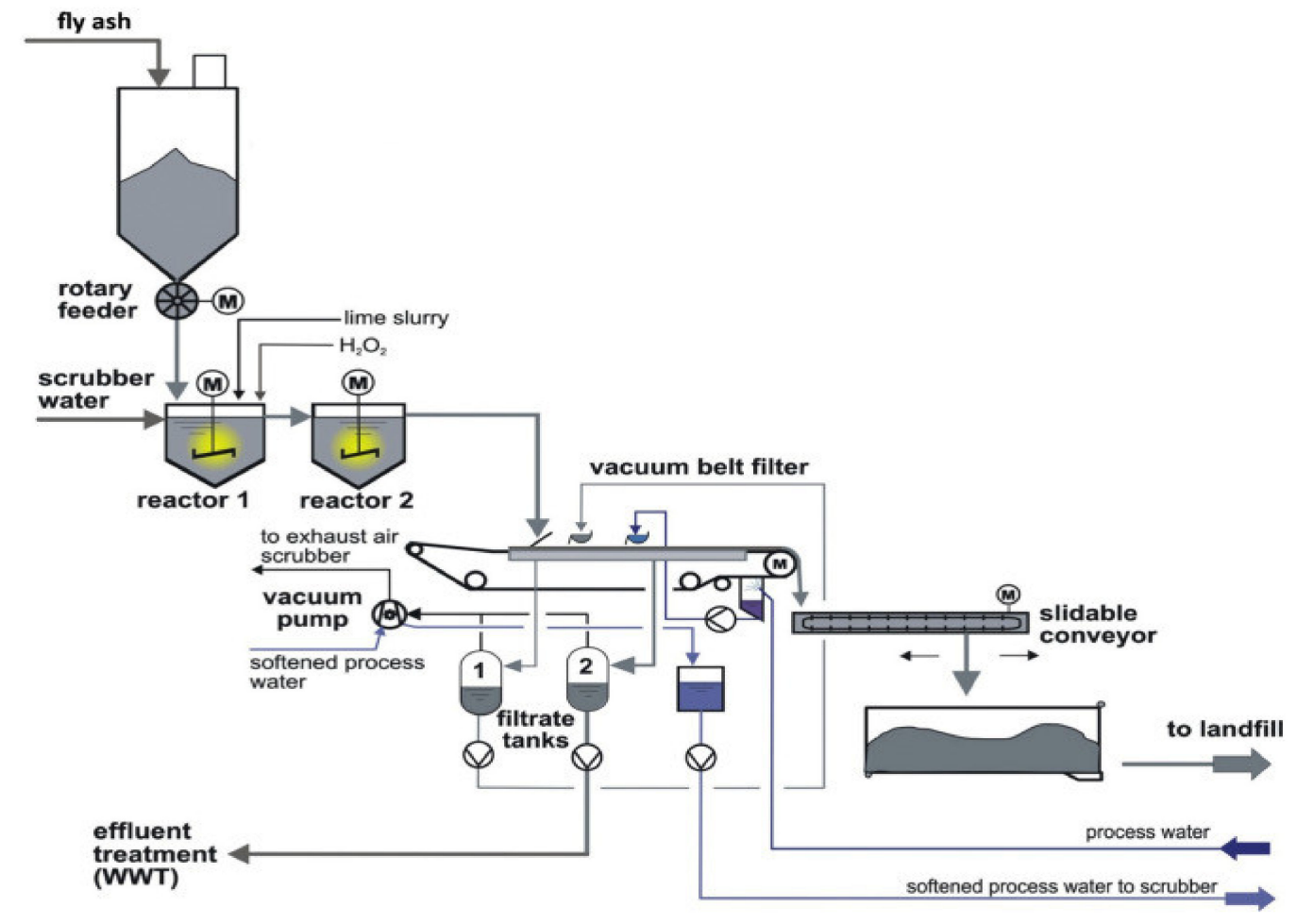

Figure 3. Basic concept of acidic fly ash leaching (FLUWA).

To date, more than $60 \%$ of fly ash in Switzerland is treated according to the FLUWA process. According to [116], during the FLUWA process, fly ash is leached using both acidic and neutral scrub water in a multistage cascade as shown in figure. Prior to fly ash leaching, mercury dissolved in the acidic and neutral scrub water is separated by a selective ion exchanger. According to [117], the extractability of metals such as $\mathrm{Zn}, \mathrm{Pb}, \mathrm{Cu}$ and $\mathrm{Cd}$ is mainly dependent on the characteristics of the FA, acidity of the scrub water, L/S ratio, redox-potential, temperature and leaching time. Furthermore, ref. [117] stated that, depending on these parameters, 60-80\% $\mathrm{Zn}, 80-95 \% \mathrm{Cd}$ and 50-85\% $\mathrm{Pb}$ and $\mathrm{Cu}$ can be extracted by the FLUWA process. During the FLUWA process, the addition of hydrogen 
peroxide helps the redox-sensitive metals $(\mathrm{Cu}, \mathrm{Pb}$ and $\mathrm{Cd})$ to stay in solution. Likewise, $\mathrm{Fe}_{2+}$ is converted into $\mathrm{Fe}_{3+}$, which precipitates as Fe-hydroxide and is accumulated in the remaining filter cake. After sufficient extraction time, the suspension is separated by vacuum belt filtration into a metal depleted filter cake and a metalliferous filtrate.

The FLUWA process provides the basis for extended methods such as the FLUREC process. This process allows for the recovery of high-purity zinc ( $\mathrm{Zn}>99.995 \%)$ from the heavy-metal-enriched filtrate. The FLUREC process was implemented at MSWI plant Zuchwil, Switzerland, in 2012, where about 300 tons of $\mathrm{Zn}$ can be recovered annually. The FLUREC process can be seen in Figure 4 . For further knowledge and research work about FLUWA and FLUREC, the research work of [115-118] can be more useful.

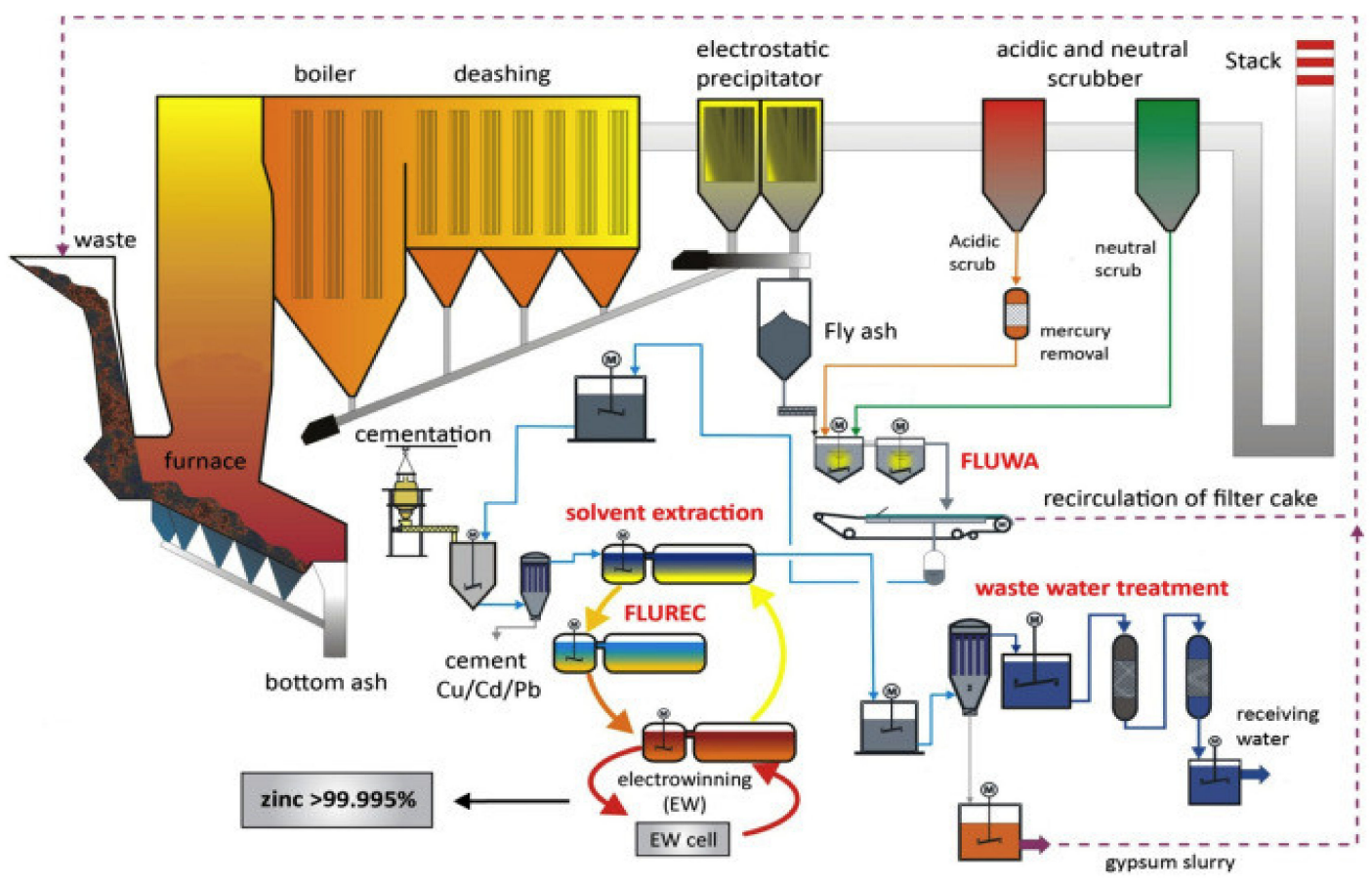

Figure 4. Process diagram of waste incineration, fly ash leaching (FLUWA) and recovery of recyclable materials (FLUREC).

\subsubsection{Electrodialytic Remediation}

Electrodialytic remediation is a technique that combines electro dialysis with electro migration of ions for the removal of heavy metals from fly ash. The basic principle of electrodialytic remediation technique involves suspension of incineration fly ash in a solution placed in electrodialytic cells. An electric current is then applied across the cells, which enables the metal ions to migrate towards the electrodes based on their charge, as shown in Figure 5.
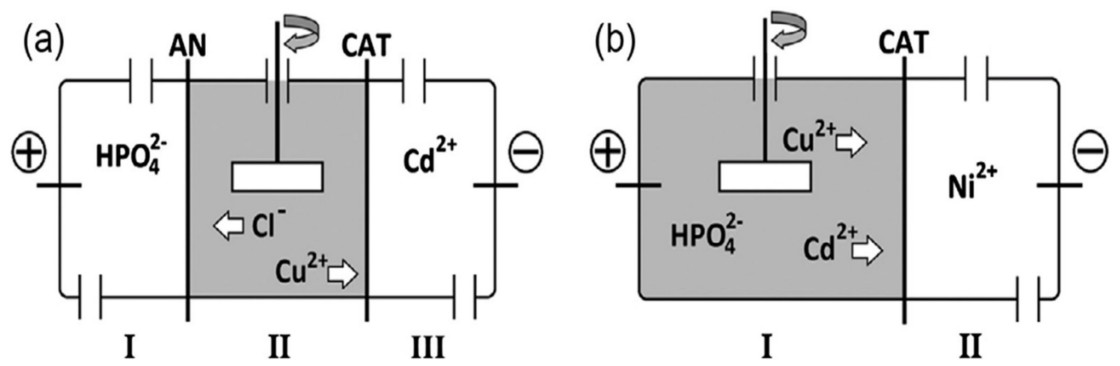

Figure 5. The (a) three-compartment and (b) two-compartment setup for the electrodialytic remediation of ash. 
The ion-exchange membranes placed between two cells prevent the metal ions from reaching the electrodes. Instead, they are accumulated in "concentration" compartments and are subsequently removed. There are several studies carried out by [119-122] to extract heavy metals with and without assistance of assisting agents (deionized water, $2.5 \% \mathrm{NH}_{3}$ solution, $0.25 \mathrm{M}$ citric acid and $0.25 \mathrm{M}$ ammonium citrate). The study by [119] used multiple experiments through three-compartment electrodialytic cells and two-compartment electrodialytic cells to remove the heavy metals, and chlorides from incineration residues according to the results of the study removal of heavy metals were generally low. The operational parameters may help to achieve somehow better results; like with low $\mathrm{pH}$, higher amounts of heavy metals can be removed. According to [119-122], removal of heavy metals was shown to be dependent on current, density and the type of incineration residue rather than type of electrodialytic cells. Although $[119,120]$ have shown optimized removal of heavy metals with the support of ancillary agents but it leaves a liquid waste which is even harder to handle because that liquid waste further necessities treatment prior to dispose or reuse [123]. Furthermore, research studies should be carried out to minimize the time consumption, which can lower the demand of continuous energy.

\subsubsection{Magnetic Separation}

Magnetic separation techniques are one of the standard frameworks to separate materials based on their magnetic properties. The magnetic separation technique includes drum magnetic separator Figure 6 and cross belt separator Figure 7 techniques. The working principle of the drum separator is that the pulp flows into cell body from the pulp box, and, under the water flow of the feeding spray pipe, the mineral grain will go into the feeding area of the cell body in the loose condition. In the magnetic field, the magnetic ore particles will have a magnetic gathering and form a magnet group or magnet chain, which is influenced by the magnetic force inside the pulp and moves to the magnetic pole and finally is absorbed onto the cylinder. The non-magnetic and weak magnetic minerals are kept in the pump and are discharged from the chute with the pulp to become tailing.

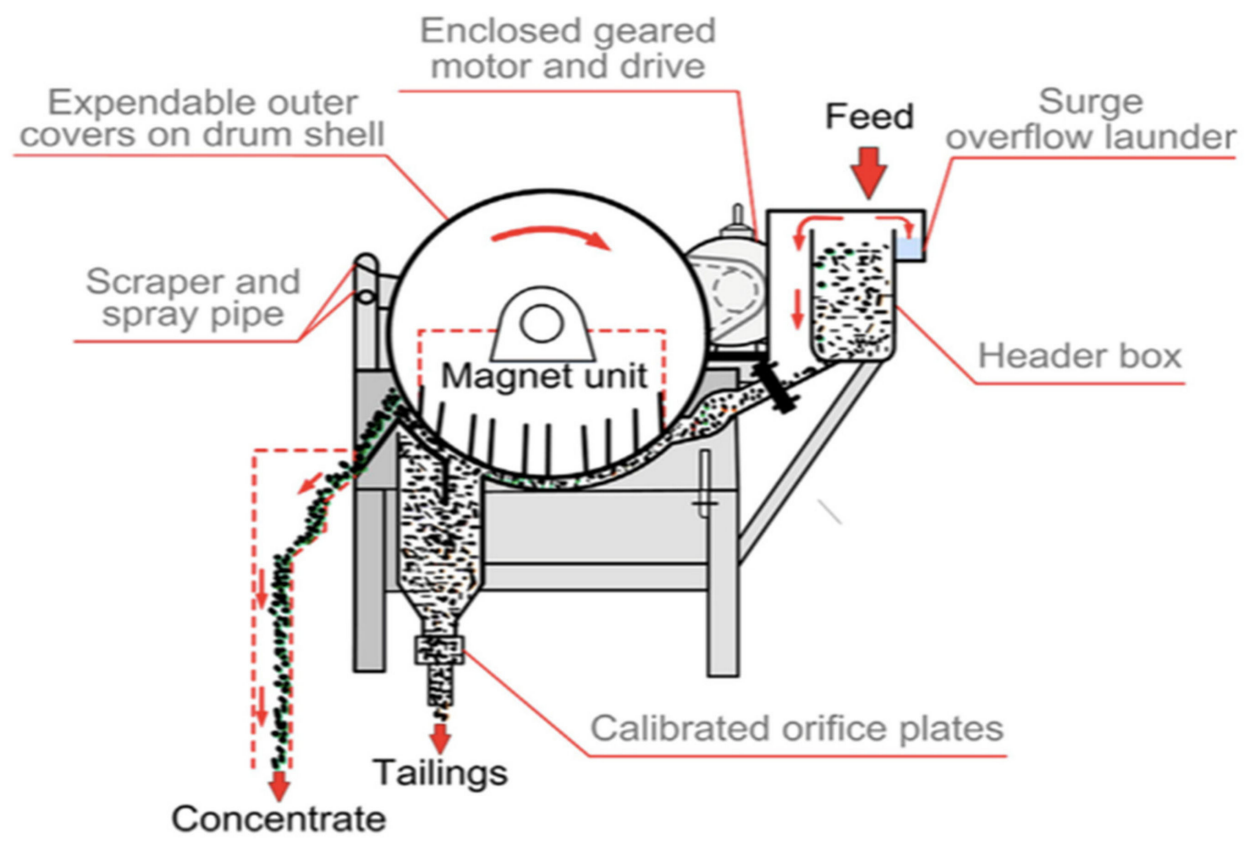

Figure 6. Shows a typical drum separator. 


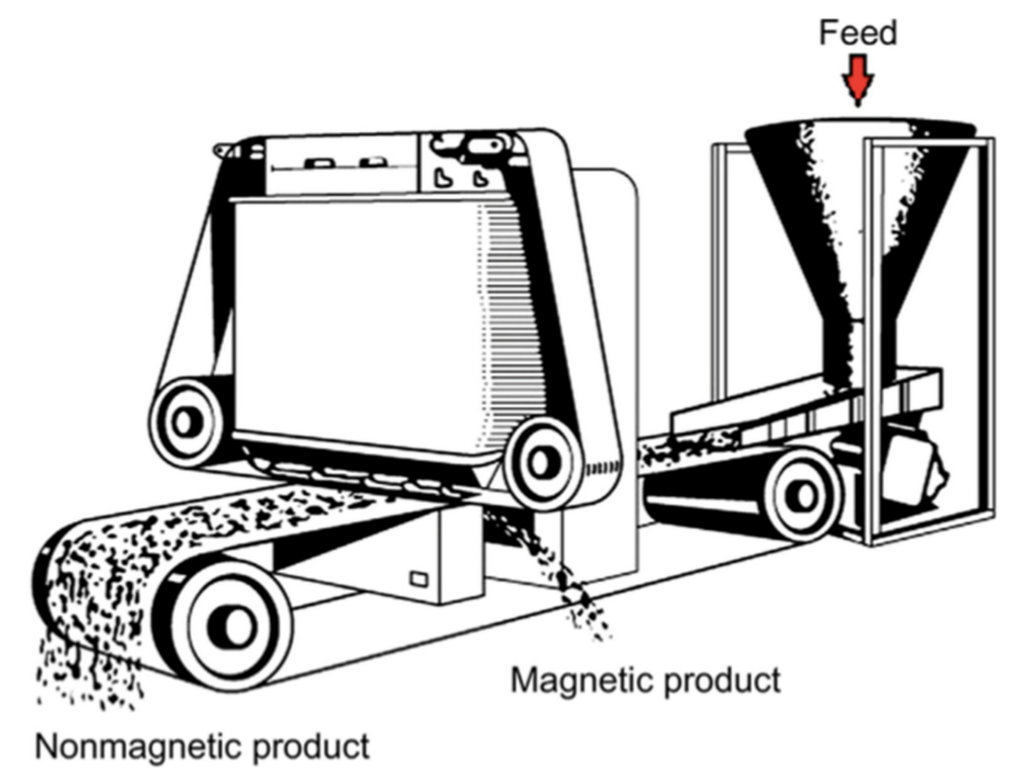

Figure 7. Cross belt separator.

In the case of a cross belt magnetic separator, the materials are uniformly fed to the belt. When materials go through the permanent magnetic drum, the non-magnetic and low-magnetic particles will leave the belt surface because of the centrifugal force and gravitation. Meanwhile, strong magnetic particles are absorbed to the belt by magnetic force and then fall into the magnetic trough when the belt leaves the magnetic pulley [124].

The magnetic density separation (MDS) works based on the difference in density between aluminum and other non-ferrous metals in a magnetic gradient field [125]. The processes developed for the treatment of MSW incineration residues for basic physical separation techniques and specifically magnetic separation are not generally investigated for the material recovery from MSW incineration residues. Only two patents were found using magnetic separation for the extraction of ferrous materials from MSW incineration residues [126]: the first patent by [127] applied separation at the end of the treatment; the second patent by [128] described the magnetic separation steps used in a mixture of water and fly ashes. Magnetic separation may lead to the recovery of a valuable ferrous fraction, as in the case of bottom ash, and, ideally, to a relative decontamination of the non-magnetic fraction. The effectives of magnetic separation reported by [129] were up to $83 \%$ for ferrous metals. Other than the recovery of ferrous material, the magnetic separation was also used for the characterization of residues by [130]. According to [130], the fly ash was first washed, then sieved and finally separated according to their density. The magnetic separations on boiler fly ashes were studied by [126], and the dry magnetic separation and wet magnetic separation were used in their study. The main drawback of such a wet separation lies in the partial dissolution of the residues, especially the heavy metal compounds leaching, once they are in contact with water. This drawback may become an advantage if the chlorides' dissolution is considered, since chlorides generally have to be removed from MSWI fly ashes. Magnetic separation could then stand for a washing step. In any case, the solution resulting from this separation should be treated before its discharge. From an economical point of view according to [126], magnetic separation appears to be beneficial only for big treatment plants. It could thus be interesting to reduce the residues to be landfilled by employing another recovery step or by improving the ash treatment.

\subsubsection{Eddy Current Separation}

The eddy's current separation (ECS) technology is a method of separation of nonferrous fraction. However, existing ECS designs are limited by particle size [131]. The limitations and principles of ECS Figure 8 are well explained by [132]. ECS demands an accurate calibration, keeping in mind the size of 
materials to be separated, and, when ECS is used on coarse and fine particles, the different rotation speed of rotors may give better results. For example, for particles larger than $5 \mathrm{~mm}$, a rotation of 2000-3000 rpm, typical for standard ECS, is appropriate. For non-ferrous metals in ashes, fine fractions $<5 \mathrm{~mm}$ may achieve high recovery efficiency.

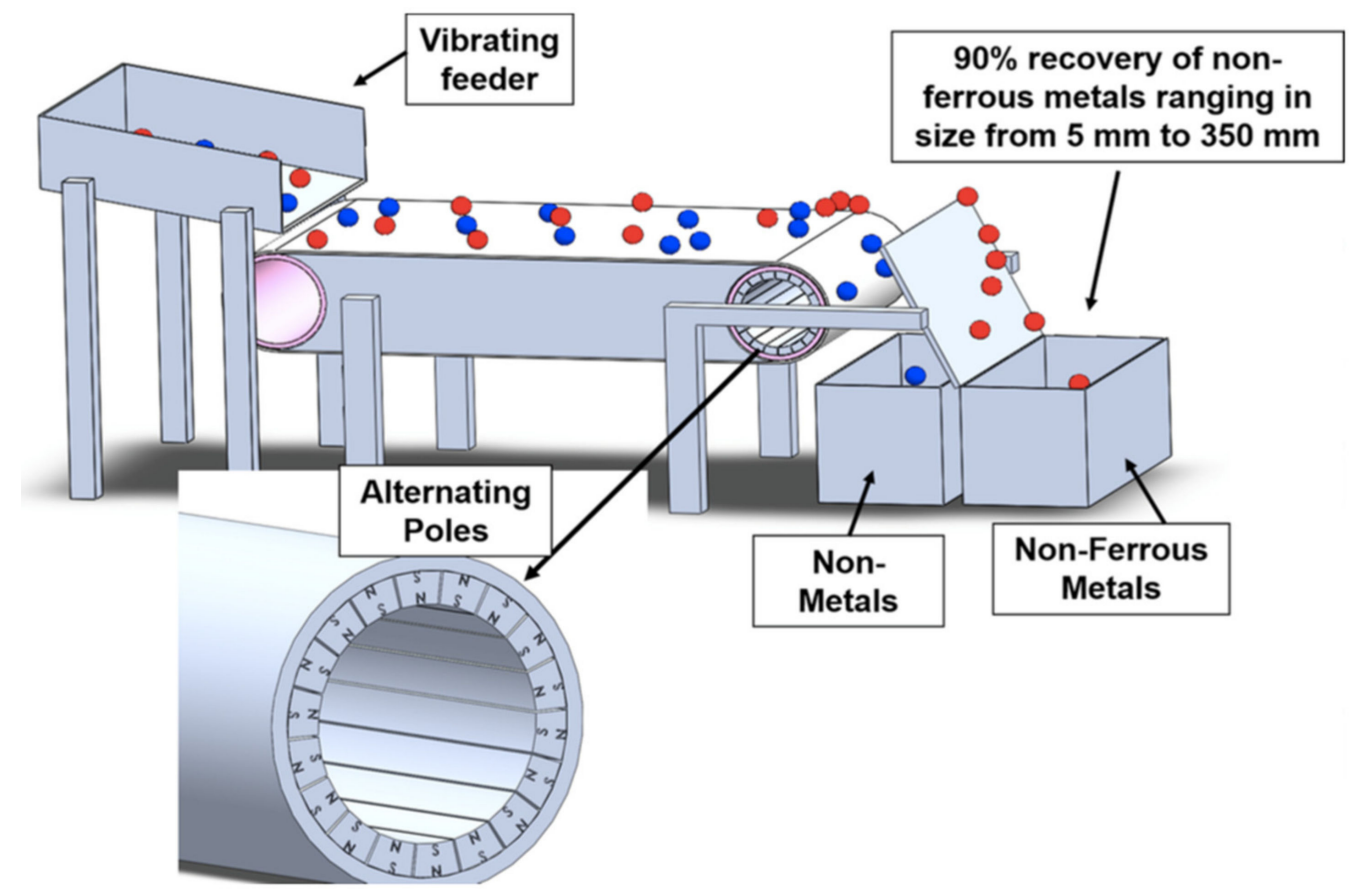

Figure 8. Description of a typical belt-driven rotary drum design of an eddy current separator.

There are other techniques present in literature but those are not developed at a full scale. Such is the case with magnus ECS, backward operating ECS and with wet eddy current separators [133-135]. The Magnus ECS is based on the "Magnus effect": a spinning particle moving through a fluid experiences a force perpendicular both to its direction of motion and to its axis of rotation. This effect can be used to recover small NFe metal particles from the bulk stream (both wet and dry) [133]. A backward operating ECS is a standard separator whose magnetic drum rotates "backwards". According to [134], if it becomes difficult to separate small metal particles from the non-metal stream when the magnetic drum rotates in "forward" mode, the yield improves drastically when it rotates in the opposite direction. In a wet ECS, the water makes it possible to glue all the particles to the belt surface. For small particles, this adhesive force has the same order of magnitude as gravity. Without the action of the rotor, therefore, virtually all particles would stick to the belt and end up in the non-metal fraction. The available literature on the subject is still in development. Reviews on the technical applications of eddy current separators have been published by [136,137] and more recently by $[138,139]$. However, the number of extensive and critical reviews on this topic is limited to date.

\subsubsection{Shaking Table}

A shaking table is a common piece of equipment in a mineral processing plant. It is widely used for gold, silver, zinc, lead, tin, tungsten, iron, manganese, and coal separating, etc. It has features of a high enrichment ratio, high separation efficiency and an easy operation. The shaking tables or wet tables are considered density separation techniques that enable the separation of heavy metals particles from other lightweight particles [80].

The structure of shaking tables contains a sloping plank with ribs on the surface. The slurry flows perpendicular to the ribs and the table swings parallel to the ribs. Mineral particles were fed from the table feeding slot, at the same time, feeding water tank fed water crossly. Under vibration wave, 
mineral particles move breadthwise and lengthways along the surface. They would be separated in different layers and discharged from different positions as concentrate, middling and gangue, as shown in Figure 9. It has been successfully employed on an industrial scale for the separation of metals such as tin, copper, gold, lead, zinc, tungsten, etc., of a size of $50 \mu \mathrm{m}-2 \mathrm{~mm}[96,97]$. However, there is little research work or literature available on shaking tables.

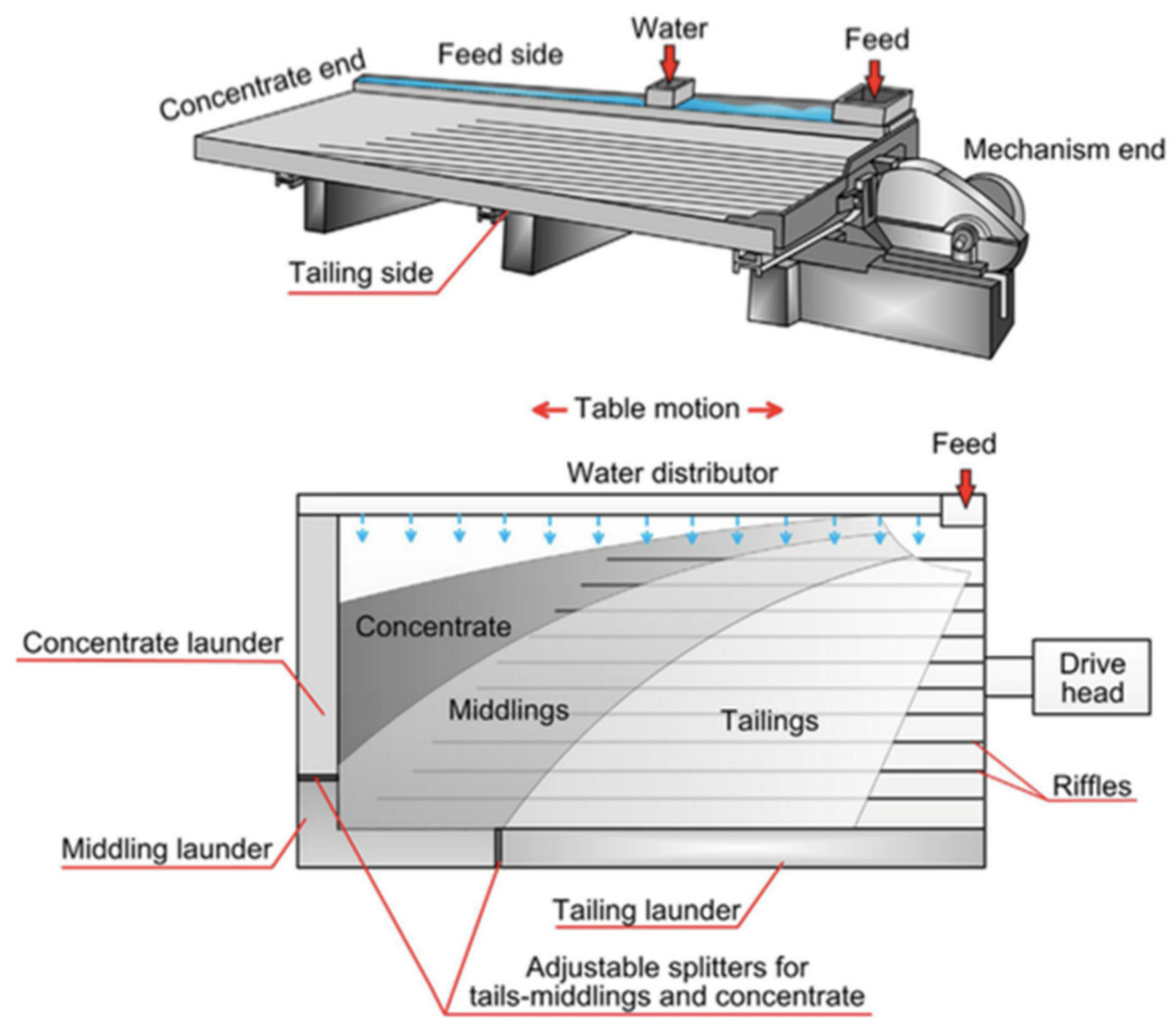

Figure 9. Shaking table.

\subsection{Stablization/Solidification (S/S)}

Stabilization/solidification are widely employed processes for MSWI residues. S/S processes tend to deal with waste residues whose properties (physical, chemical and mechanical) favor reducing the leachability of contaminants from waste [23]. The solidification/stabilization indicates the processes, which involve additives or binders to either physically or chemically immobilize the hazardous content in waste [22]. The goal of the stabilization process is to decrease the toxicity and solubility of contaminants to make it less soluble and less toxic with or without solidification. Contrastingly, in solidification in order to lessen the leachability and to immobilize contaminants, binders such as cement are usually added. This process reduces the mobility of contaminants in the treated material through encapsulation. The best approach to solidification/stabilization in practice is to initially involve chemical stabilization and then solidification of waste [25]. The addition of inorganic binders such as Portland cement for solidification/stabilization has been in practice for a long time in several parts of the world. Numerous research studies have shown that cement solidification can fix the heavy metals [140-142]. However, heavy metals in cement-solidified products are not stable in the long term and also the exposed environment may increase the leaching ability of heavy metals. Considering the long-term leaching characteristics of solidified products, an effect on heavy metals is shown by aging or carbonation [143]. The study carried out by [144] reported that supercritical carbonation can enhance/accelerate the aging characteristics of solidified products. The study conducted by $[145,146]$ 
used supercritical carbonated cement product to study the heavy metals' leaching characteristics and found that supercritical carbonation promoted the leaching of $\mathrm{Cu}$ and $\mathrm{Pb}$. Furthermore, not all heavy metals can be fixed through solidification such as Hg. In the study of [147], it was shown that $\mathrm{Hg}$ released by the solidified products reaches $8.51 \mathrm{ng} / \mathrm{g}-18.48 \mathrm{ng} / \mathrm{g}$, resembling that of raw fly ash. Additionally, the increase in temperature and water content also promoted the release of Hg. According to [25], this process has a drawback, which makes it ineffective for the treatment of soluble salts and in return long-standing leaching will bring an environmental issue. During this process, the significant increase in volume of waste may occur, which may affect shipping and the landfill costs [21].

The introduction of new stabilization technique by [148] is shown to be capable of destroying the toxic content, reducing the heavy metal reactivity and solidifying the hazardous waste beyond the leaching limit. This four-stage technique involved: elimination of alkali chlorides by solidification; addition of phosphoric acid; calcination and solidification with cement. [22]. The combined treatments, such as washing-immobilization treatments, can possibly remove noteworthy quantities of sulfate and mainly chloride from incineration fly ash. This treatment would encourage the development of the hydrate phase, which will change the heavy metals into less reactive forms. Afterward, the water remained as waste after washing treatment could be treated as explained by [149]. This treatment can not only help to treat the incineration fly ash and stabilize it in cement with any issue of heavy metals leaching but can also reduce the cost to make this treatment economical.

\subsection{Thermal Treatment}

The thermal treatments are aimed to acquire stabilization in the residue, which is resistant to leaching and creating a residue for utilization. Thermal treatment thus ensures the maximum detoxification of residue. In contrast to this, ref. [149] reported the threat by the presence of alkali chlorides, sulphates and volatile compounds during the thermal treatments. Therefore, these processes involve high temperatures, which increases the cost but creates a possibility for the removal of pollutants and toxic materials [21,149]. The research contribution by [150] reported an option to dodge heavy metal volatilization, achieving immobilization in a specific atmosphere, use of additives, temperature and pretreatment. As thermal treatment undergoes an air control system, ref. [151] reports to take measures for cooling methods because it may influence the characteristics and leaching behavior of residues. The major thermal treatments are grouped as sintering, vitrification, melting and thermochemical treatment.

\subsubsection{Sintering}

The sintering can be defined as the temperature-induced coalescence where densification of porous solid materials occurs below the melting point. The treatment temperatures involved in the sintering process are generally between 700 and $1200{ }^{\circ} \mathrm{C}$ [33,45,151-154]. Sintering involves heating the fly ash to the point at which particle bonding occurs and chemical phases in the fly ash reorganize, then the solid phase transformation and recrystallization occurs, which results in a product with lower porosity and with higher density and strength. The sintered product with lower porosity tends to eliminate the chances of leachability from the final product.

Several studies have been performed to investigate the effects of sintering on incineration ash, incineration fly ash, incineration bottom ash and mixture of FA and BA [104,107-109,152-156]. According to the research study carried out by [157], it was found that the sintered heavy metals $(\mathrm{Zn}, \mathrm{Cr}, \mathrm{Pb}$, and $\mathrm{Cu})$ were mainly present in an oxidized form. Except $\mathrm{Pb}$, the leaching concentrations of most of the heavy metals were within the limits of the national standard. No significant increase was seen in the leaching concentrations of heavy metals even after 30 days of aging of sintered products. The operational conditions, such as sintering time and treatment temperature, may have an influence on the solidification of heavy metals. Therefore, to establish an overall pollution toxicity index (OPTI), a study was conducted by [158] for the evaluation of heavy metal pollution. According to 
experimental results, higher sintering temperature led to more volatilization of heavy metals, and the lowest value for the overall pollution toxicity index (OPTI) was at $1040{ }^{\circ} \mathrm{C}$. The authors of [159] conclude that, at lower temperatures and shorter times, higher integrated control efficiency conditions of heavy metals were achieved. Some suggested various pretreatments such as water washing, ball milling, sieving and pelletizing of the ash [154,160-163]. These pretreatments are comparable to traditional ceramic processing as the glass-ceramics produced by the sintering process often undergoes pre-melting [164]. The study on untreated fly ash by [155] proved to be ineffective for the production of concrete aggregates, because of the adverse chemical characteristics of these fly ashes in terms of chloride, sulfate, and vitrifying oxide contents. Contrastingly, to counter the presence of soluble salts, water-washing treatment can enhance the chemical properties of sintered products, which, according to [152], satisfies the basic requirements for concrete aggregates. Water washing treatment is not only effective for the removal of metal chlorides but also serves as the effective tool for reducing the sintering temperature and treatment time. Although water washing lowers the power consumption during the sintering, it would require further treatment for wastewater generated.

\subsubsection{Melting/Vitrification}

The melting/vitrification is derived from the metallurgical industry. The melting and vitrification of fly ash involves higher temperature ranges from 1000 to $1600{ }^{\circ} \mathrm{C}$. In the melting process, the organic part of the MSWI fly ash is decomposed, whereas the inorganic part is transformed into a glass slag via crystal phase transformation [21,23]. In contrast to this, vitrification is a process of melting residues with glass-forming additives or other waste solids to create a homogenous liquid phase, and then cooled to form an amorphous, homogenous single-phase glass. In the melting process, the temperature required for the melting process depends upon the composition of fly ash [21-26]. The melting/vitrification process generally involves fossil fuel and electric heating. The fuel burning melting/vitrification involves fuel oil, coke and gas. In this regard, a detailed study is presented by [82], which summarizes the properties of fuel burning and electric melting/vitrification furnaces and systems. The volatilization of heavy metals during melting/vitrification processes is studied by several researchers [165-169]. The low volatile heavy metals are transformed and solidified in the dense lattice structure of melted slag, thereby reducing their leaching rate. However, the easily and semi-volatile heavy metals in fly ash exist in the secondary fly ash during the melting process. The volatilization of these heavy metals is related to the high content of $\mathrm{Cl}$ in the raw fly ash. According to the research study of [167], the volatilization of $\mathrm{Cl}$ in a fly ash melting furnace is directly related to the molar ratio of $\mathrm{Cl} /(\mathrm{Na}+\mathrm{K})$ in the raw fly ash sample. A higher $\mathrm{Cl} /(\mathrm{Na}+\mathrm{K})$ molar ratio promoted the volatilization of $\mathrm{Cl}$, leading to the detection of more $\mathrm{PbCl}_{2}$ in the secondary fly ash. Similarly, the finding of [168] shows that low volatile heavy metals $(\mathrm{Cr}, \mathrm{Ni})$ were better solidified in the melting slag. Contrastingly, the easily and semi-volatile heavy metals such as $\mathrm{Hg}, \mathrm{Cd}, \mathrm{Pb}$, and $\mathrm{Zn}$ are difficult to stabilize. Plasma is currently an area of in electric melting/vitrification. The high-energy-density and high-temperature of a plasma flame can promote the melting/vitrification reactions and reduce the residence time of MSWI fly ash. Related research [169-172] has shown, after plasma melting/vitrification treatment, the volume reduction of MSWI fly ash. The volatilization and leaching characteristics of heavy metals before and after plasma melting/vitrification [169-171,173] determined that most heavy metals sealed in vitreous slag are $\mathrm{Cr}$, and $\mathrm{Ni}$, which are low volatile heavy metals. In comparison, $\mathrm{Cd}$ and $\mathrm{Pb}$ exhibit a strong volatile property. The leaching of other heavy metals in melting/vitrification slag such as $\mathrm{Zn}$ and $\mathrm{Cu}$ is significantly lower than that of the original fly ash, which proves that vitreous slag can seal the heavy metals from fly ash.

\subsubsection{Thermochemical Treatment}

China is increasingly shifting towards incineration because of its small land footprint, huge waste volume reduction and energy recovery. However, incineration residues such as fly ash and bottom ash contain toxic substances, heavy metals, which become problematic if disposed/reused without treatment. 
There are two main options to handle fly ash in terms of heavy metals: either reducing the heavy metals' leachability by stabilization or the recovery of heavy metals from fly ash. Thermal treatment of fly ash causes stabilization and the recovery of heavy metals depending on the treatment temperature. Thermal treatment contains three major ways (vitrification, fusion/melting, and sintering) to stabilize the heavy metals. The heavy metals stabilization/removal through vitrification, sintering and melting seems to be energy consuming compared to the removal of heavy metals by thermal treatment with the addition of chlorinating agents. Heavy metal chlorides exhibit a higher vapor pressure; thus, involvement of $\mathrm{Cl}$ helps to delay the condensation of these metal compounds during thermal treatment. This situation quickens the removal of heavy metals. Accordingly, for the effective removal of heavy metals from MSWI fly ash, the addition of a certain amount of chlorinating agents with MSWI fly ash can lead to an effective removal of heavy metals. Typically, the metals of interest are $\mathrm{Zn}, \mathrm{Cu}, \mathrm{Pb}$ and $\mathrm{Cd}$. The reaction mechanism of chlorinating agents described by [174-177] has shown promoting effects on the removal of heavy metals. The volatility of trace elements is divided into several categories by research studies according to their nature of volatility as easily volatile $(\mathrm{Cd}, \mathrm{Pb})$, semi-volatile $(\mathrm{Cu}, \mathrm{Zn})$ and low volatile $(\mathrm{Cr}, \mathrm{Ni})$. Cadmium and lead tend to be volatized during the combustion process. Table 7 shows an overview of previous studies and the experimental parameters used for the removal of heavy metals from fly ash. According to [178], the part of heavy metal removal can be improved by wetting the mixture of fly ash and adding the chlorinating agents with water and later drying it to improve the contact area. In contrast to this, ref. $[179,180]$ states that pelletizing the fly ash plus adding the chlorinating agents mixture prior to treatment may decrease the entrained particles, which can result in a low removal rate of copper. The availability of chlorine and the formation of metal chlorides may strongly increase the volatility of metals. Semi-volatile metals like Zn may act contrarily depending on the conditions of the waste to energy ( $\mathrm{WtE}$ ) plant. If the chlorine is available, the $\mathrm{Zn}$ can volatilize as atomic $\mathrm{Zn}$ at reducing conditions or as $\mathrm{ZnCl}_{2}$, whereas $\mathrm{ZnO}$ is easily formed under oxidizing conditions and has very low volatility. Therefore, its essential to use chlorinating agents to increase the volatization of these trace metals from fly ash. There are several chlorine additives used as can be seen in Table 7 to achieve the required vaporization. Amongst all the chlorine additives, $\mathrm{MgCl}_{2}$ has shown effective results. The removal of $\mathrm{Cu}, \mathrm{Zn}, \mathrm{Pb}$, and $\mathrm{Cd}$ by different studies using different chlorinating agents is $80-95 \%, 75-97 \%, 99 \%$ and $99 \%$, respectively.

There are several factors, which can influence the removal of heavy metals. The higher treatment temperature and longer residence time can help to achieve a better removal of heavy metals. However, the temperatures exceeding the melting range may affect the evaporation. The lower temperatures affect the residence time greatly [174-180]. There are some processes commercially available such as the ASH DEC process for the removal of heavy metals from MSWI fly ash and sewage sludge ash. Similarly, ref. [174-176,179-181,183-186] have formed the basis for the ASH DEC process, as it already existed at a commercial level for the recovery of phosphorus from sewage sludge ash. In this model, ash is well mixed with water and chlorinating agents $\left(\mathrm{MgCl}_{2}\right.$ or $\left.\mathrm{CaCl}_{2}, \mathrm{KCl}\right)$. At first, the ash is treated at $300{ }^{\circ} \mathrm{C}$ for about $30 \mathrm{~min}$ and then at $900-1100{ }^{\circ} \mathrm{C}$ for a maximum of $60 \mathrm{~min}$. During this process, the metal chlorides formed are captured in the flue gas cleaning system and later recover with the following treatment. 
Table 7. Overview of previous studies and their experimental parameters for the removal of heavy metals from fly ash.

\begin{tabular}{|c|c|c|c|c|c|c|}
\hline Incineration Ash Type & Chlorinating Agents & Heating Source & Temperature & Metals Studied & Time (Minutes) & Reference \\
\hline Fly ash & $\mathrm{MgCl}_{2}$ & Muffle furnace & $1100{ }^{\circ} \mathrm{C}$ & $\begin{array}{l}\mathrm{Cd}, \mathrm{As}, \mathrm{Pb}, \mathrm{Zn}, \mathrm{Cu}, \\
\mathrm{Cr} \text {, and } \mathrm{Ni})\end{array}$ & & [177] \\
\hline Fly ash & $\mathrm{CaCl}_{2}$ & Rotary reactor & 950,1000 and $1050^{\circ} \mathrm{C}$ & $\mathrm{Cd}, \mathrm{Pb}, \mathrm{Cu}$ and $\mathrm{Zn}$ & 10,15 and 25 & [181] \\
\hline Fly ash & $\begin{array}{c}\mathrm{HCl} \text { gas, } \mathrm{CaCl}_{2}-2 \mathrm{H}_{2} \mathrm{O} \\
\mathrm{MgCl}_{2} \cdot 6 \mathrm{H}_{2} \mathrm{O}, \mathrm{MgCO}_{3}+\mathrm{HCl}\end{array}$ & $\begin{array}{l}\text { Quartz glass reactor, } \\
\text { laboratory scale gas-tight } \\
\text { rotary furnace }\end{array}$ & $1000^{\circ} \mathrm{C}$ & $\begin{array}{l}\mathrm{Cd}, \mathrm{As}, \mathrm{Pb}, \mathrm{Zn}, \mathrm{Cu} \text {, } \\
\text { Cr, Mo and } \mathrm{Ni})\end{array}$ & 30 & [182] \\
\hline Fly ash & $\mathrm{CaCl}_{2}$ & Rotary kiln and FBR & 800,850 and $900^{\circ} \mathrm{C}$ & $\mathrm{Cd}, \mathrm{Pb}, \mathrm{Cu}$ and $\mathrm{Zn}$ & & [180] \\
\hline Fly ash & $\mathrm{MgCl}_{2} \cdot \mathrm{H}_{2} \mathrm{O}$ & Tube furnace & $900-1000^{\circ} \mathrm{C}$ & $\mathrm{Cu}, \mathrm{Zn}$ & & \\
\hline Fly ash & $\mathrm{CaCl}_{2}$ & Quartz tube furnace & $950{ }^{\circ} \mathrm{C}$ & $\mathrm{Zn}$ & 240 & [183] \\
\hline Fly ash & $\mathrm{CaCl}_{2}$ & Laboratory-scale rotary kiln & $900-1000{ }^{\circ} \mathrm{C}$ & $\begin{array}{l}\mathrm{Cd}, \mathrm{As}, \mathrm{Pb}, \mathrm{Zn}, \mathrm{Cu}, \\
\mathrm{Cr} \text {, and } \mathrm{Ni})\end{array}$ & 30 & [184] \\
\hline Fly ash & $\mathrm{MgCl}_{2}$ & $\begin{array}{l}\text { Pilot scale indirectly heated } \\
\text { rotary kiln }\end{array}$ & $900-1100{ }^{\circ} \mathrm{C}$ & & 40 & [185] \\
\hline Fly ash & $\begin{array}{c}\text { Mixture of chlorinating } \\
\text { agents }\end{array}$ & Directly heated rotary kiln & $900-1100{ }^{\circ} \mathrm{C}$ & $\mathrm{Cu}, \mathrm{Zn}$ & 30 & [186] \\
\hline Fly ash & $\mathrm{MgCl}_{2} \cdot 6 \mathrm{H}_{2} \mathrm{O}$ & Tube furnace & $900-1000{ }^{\circ} \mathrm{C}$ & $\mathrm{Cu}, \mathrm{Zn}$ & 30 & [157] \\
\hline
\end{tabular}




\section{Possible Application of Incineration Fly Ash}

The emergence of recycling philosophy has encouraged the recovery, recycle and reuse of the incineration ash. Thus, the use of landfills for incineration ash disposal is decreasing year by year in many countries. Incineration ash is rich in heavy metals and soluble salts, which may appear as an alternative resource to existing scares and precious natural resources. Literature unveils the availability of huge information on the applications of waste $[12,17,21-23,25]$. Each application for fly ash reuse, recycle and recover comes with advantages, for example, the conservation of natural resources, elimination of waste and availability of zero-cost raw materials.

In this section, we mainly focused on identifying the processing suitability, performance, and environmental impact of incineration fly ash for its applications and finally, at the end of this section, Figure 10 summarizes the utilization sources, development stage and the limitations faced.

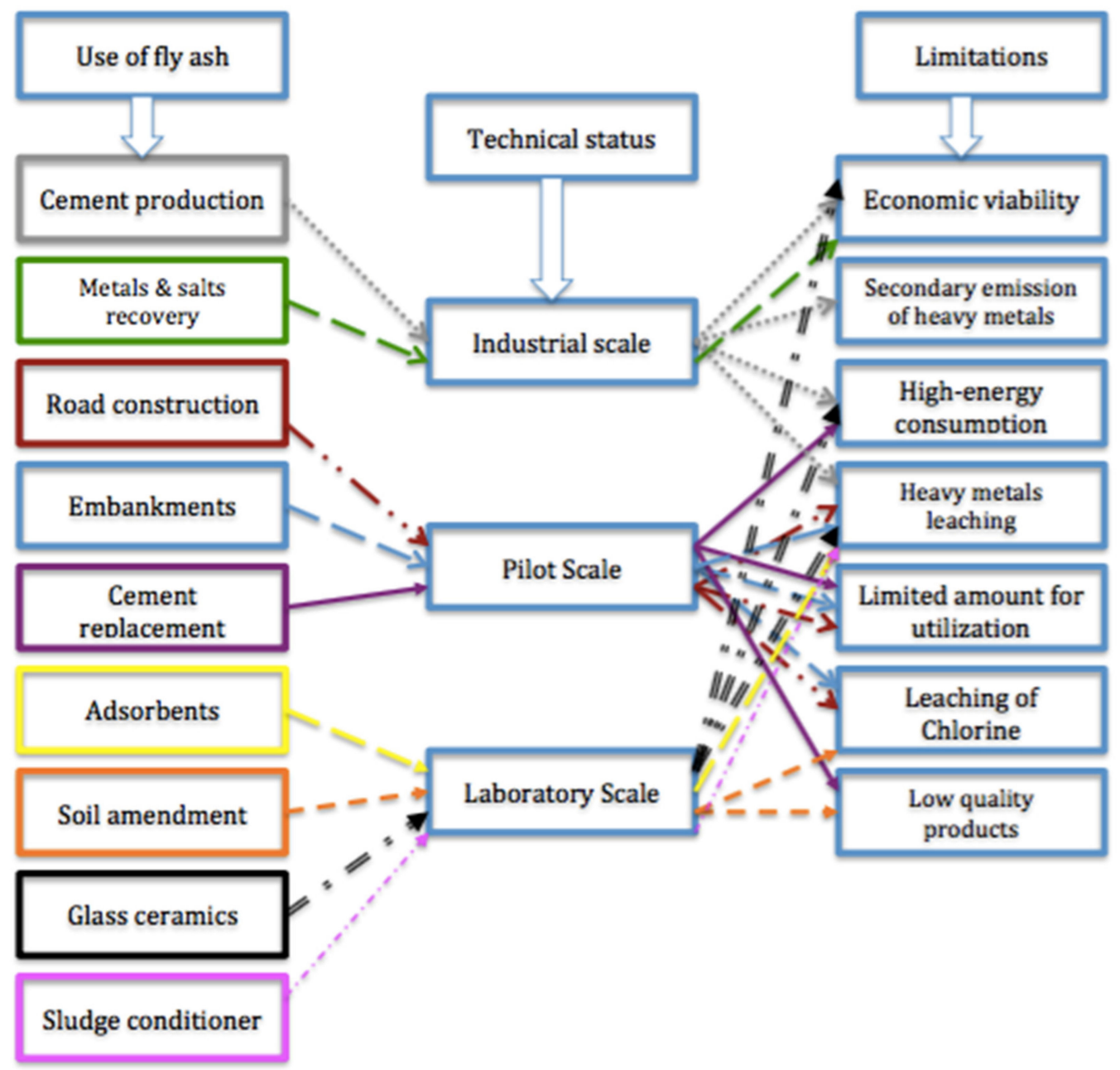

Figure 10. Use of fly ash, technical status and the limitations faced.

\subsection{Construction Material}

\subsubsection{Cement}

\section{Cement Process/Production}

The availability of lime, silicates and aluminosilicates in incineration ash matches the elemental composition of cement, thus making it possible substitute for cement raw materials [19-25]. The cement processing and production requires a huge amount of energy; therefore, cement production is also regarded as an energy-intensive process. The decarbonization of calcium carbonate into quicklime is 
the main energy consumer in cement processing, and each ton of clinker that is produced emits a similar quantity of carbon dioxide into the atmosphere. The incineration ash contains lime, which can help in the reduction of carbon dioxide. However, there are a few technical issues that discourage the use of this application, such as higher chloride content, which can possibly affect the products' quality, and cycling effect in the cement kilns may become the basis of clogging and corrosion inside the heat exchangers. The presence of heavy metals in higher concentrations may also affect the chemical composition of cement and afterward creates an environmental burden. Therefore, pretreatment procedures are required to treat and remove the chloride and heavy metal content. Taking into account the hydration behavior of cement clinker, it is observed that the content of alkali metals increases the hydration and that the content of $\mathrm{Zn}, \mathrm{Cd}$ and $\mathrm{Pb}$ impedes the rate of hydration of cement. The content of alkali metals in MSW incineration ash is reduced after washing pretreatment, and the hydration rate of treated MSW incineration ash clinker is lower than that of untreated MSW incineration ash clinker [187-191]. The use of MSW incineration fly ash may also serve as a material for lightweight concrete aggregate by handling through pellets. This could be used in non-structural forms, for example, as interior walls for insulating purposes [192]. Cement-solidified MSW incineration fly ash has been reported to be useful for safety reuse as artificial aggregate in Portland cement mortars, and the study conducted by [193] has shown low leaching levels of heavy metals, having a high compressive strength without any delay in mechanical strength improvement for the mortars incorporated into aggregates. Even though leaching is regarded as the main drawback or environmental concern for the application of MSW incineration ash, in Japan, a brand named Ecocement has made an attempt at involving large amounts of ash in cement clinker [188]. Furthermore, to expand and involve applications of incineration, ash requires pretreatment, and the quantity of incineration ash required to add to the chosen process must be sensibly controlled to achieve and ensure the required product quality and process safety.

\subsubsection{Glass Ceramics}

The ceramics industry produces pottery, porcelain and building materials (bricks, tiles, stoneware, etc.). The ceramic products are made of malleable and earthy materials such as clay, and higher temperatures play an important role in making them harder. To help retain shape and face the higher temperatures, inert materials such as quartz are used to confer the cohesion, plasticity and structural support of ceramic product. The silica is also used with a combination of melting agents and stiffeners for glazing ceramic bodies. According to [194], when a glaze layer is applied on a ceramic product and then fired, the glaze components are melted into a vitreous material. The ceramic industry utilizes a huge share of natural raw materials, and the incineration residues such as bottom ash (BA) and fly ash (FA) hold higher amounts of $\mathrm{SiO}_{2}, \mathrm{Al}_{2} \mathrm{O}_{3}$ and $\mathrm{CaO}$, which enables them to substitute part of the natural raw materials for the ceramic production without pretreatment. However, fly ash (FA) contains high quantities of heavy metals and iron oxide, which may adversely impact the ceramic product. However, ref. [195] suggests that this problem could be resolved by choosing an appropriate amount of incineration fly ash. The studies by $[21-23,25]$ have presented a detailed review on ceramics.

\subsection{Geotechnical Applications}

\subsubsection{Road Construction}

Increasing urbanization and industrialization demands a transportation network of all-weather hard-surfaced roads/routes. The construction of roads requires lots of materials, one of which is sand or cement bases. Incineration ash is technically feasible for road construction and can serve as an alternative to sand and cement bases and sub-base [196], but the presence of heavy metals poses a threat to soil and underground water. The use of incineration ash as a raw material for the construction of roads serves two goals: firstly, it reduces the consumption of natural resources; secondly, it is a successful step towards "zero landfill" [197]. Usually, the main problem with using incineration ash is its leaching potential, which contaminates the environment, soil and water system. Several research 
studies [198-202] have been carried out to characterize the long-term consequences of leachate and its impact on the environment and reuse. According to [198], the leachate $\mathrm{pH}$ and concentrations in major elements $(\mathrm{Ca}, \mathrm{Na}$ and $\mathrm{Cl})$ as well as in $\mathrm{Al}$ and heavy metals $(\mathrm{Cu}, \mathrm{Pb}$ and $\mathrm{Zn})$ quickly drop during the first 2 years to asymptotically reach a set of minimum values over 10 years. The authors of [198] propose continuous field experimentation to assess the environmental impact in different times and seasons that would allow for a better recycling strategy of incineration ash. According to their results, the $\mathrm{Cu}$ and $\mathrm{Zn}$ of the test road show a geochemical anomaly compared to the surrounding area. The $\mathrm{Zn}$ has low initial leaching, which will increase with time and will in long term exceed that of the test road and surroundings. In contrast to this, the leaching of $\mathrm{Cu}$ from the test road is initially high, but decreases over time and is, in the long term, below the values of natural weathering. Similarly, the study conducted by [185] shows an increase in Zn over time with the use MSWI ash. To avoid this problem, pretreatment and use of additives can play a crucial role.

\subsubsection{Embankments}

Embankments are primarily constructed of soil and stones to resist water for land reclamation and retaining walls. It has been a common practice to stabilize the soil with lime and cement to achieve geotechnical properties. This stabilization increases the shear strength and reduces soil compressibility. Incineration ash possesses pozzolanic characteristics, which becomes the advantage for reusing it in the construction of embankments. The incineration ash alone can be mixed with soil for its possible applications [203]. The main issue with constructing embankments with incineration ash is the same as using it in the construction of roads-the possible contamination of groundwater and soil. The studies by [204] reported the comparison of incineration ash stabilized with lime and cement. According to [204], the study carried out by [203] limited their focus only on the leaching of incineration ash, but they did not consider the aftermath for the soil system; this could have shown a precise indication of leaching behavior from embankments constructed with a mixture of incineration ash and soil. Pretreatment is suggested by [205] as a possible solution for leaching.

\subsection{Adsorbent}

With the economical stability and demands of people, an increase is seen in industries such as textile, leather, food, cosmetics, paper and printing to meet people's demands. However, these industries use dyes to color their products, which result in the generation of colored wastewater [206-208]. The adsorption technique is a broadly accepted and low-cost alternative to activated carbon to eliminate pollutants from dye. The treatment for the removal of dyes can be categorized as chemical, physical and biological treatments. A research study by [206-208] showed that adsorption is the most effective physico-chemical process to remove dyes. According to [202], the adsorption mechanism can be influenced by $\mathrm{pH}$, particle size, adsorption dosage, and temperature and contact time. Although, MSWI fly ash has a lower content of $\mathrm{SiO}_{2}$ and $\mathrm{Al}_{2} \mathrm{O}_{3}(15-30 \%)$, but different types of zeolites have been synthesized by utilizing the MSWI fly ash by fusion or hydrothermal process [209,210]. The study carried out by [211] involved converting MSWI ash to zeolitic-type adsorbent materials by using hydrothermal conversion. The converted MSWI ash has shown encouraging results for application as a sorbent towards several heavy metals. The performance was found to be much better than clinoptilolite natural zeolite; around an $80 \%$ reduction in heavy metal concentration was achieved through converted MSWI ash. The results of experiments conducted on MSWI fly ash reported by [212] from landfill leachate showed that that, upon increasing the dosage of MSWI fly ash, the rate of heavy metals removal increased in the leachate.

\subsection{Agriculture}

Enriching soil and fostering the plant growth application of fertilizers are commonly adopted worldwide. The main composition of fertilizers contains three main elements-nitrogen, potassium and phosphorus. Fly ash is regarded as the second largest source of potassium and phosphorus. This certifies 
that incineration fly ash can replace the commercial fertilizers and that there is hope for scarce natural resources.

\section{Soil Amendment}

The use of incineration ash as a potential fertilizer studied by [213] showed that plant growth in amended soils was twice the time of that in non-amended soils. In addition, incineration ash can substitute lime to reduce soil acidity. The authors of [214] determined the efficacy of incineration ash in agriculture using a liming agent. The ash characterization and chemical composition holds a decisive role in providing the required results. Incineration fly ash serves as a potential fertilizer, but it has also serious environmental issues. Regarding the impact of heavy metals, several research studies have pointed out their concerns [21-26]. The use of incineration ash increases the risk of salinity. Excess salinity in soil water can decrease plant available water and cause plant stress. Salinity becomes a problem when enough salts accumulate in the root zone to negatively affect plant growth. Excess salts in the root zone hinder plant roots from withdrawing water from the surrounding soil. The increase in salinity has resulted in a decrease in crop productivity [215]. To avoid the restriction of incineration fly ash as fertilizers, an appropriate pretreatment can play vital role in reducing the salt content and to some extent the heavy metal content.

\subsection{Sludge Conditioner}

Sludge contains up to $95 \%$ of water content, which requires dewatering treatment to achieve a reduced volume. The disposal of sludge and incineration ash is not only expensive but also demands a huge area of land, which erupts with environmental problems if left untreated. From the viewpoint of solid waste management, the best way to reduce the amount of sludge and incineration ash to be disposed is to reuse them by possibly combining sludge and fly ash mixture. However, both wastes contain a certain level of pollutants, especially heavy metals, depending on the characteristics of both wastes. The main concern for the solid waste management is that the leachates from both the wastes or their products should not pose any issues regarding contamination. Several studies have been carried out to investigate the possibilities of combining both wastes and reusing them. The study carried out by [216] says that the presence of oil in small amounts makes it harder to dewater the sludge. To avoid this issue, sludge can be conditioned with filter aids. The addition of MSWI fly ash decreased the specific resistances and capillary suction times of oily sludge with up to the $3 \%$ dosage. The total suspended solids of filtrate decreased with fly ash dosage, but the toxic concentrations of heavy metals increased considerably [216]. Based on the studies conducted, it is observed that the variations in the characteristics of fly ashes and the sludge are based on their operational parameters, which suggests that, to draw conclusive and beneficial results, further testing and studies are required before establishing a best approach for sludge conditioning with fly ash.

\section{Conclusions}

Urban population proportion is increasing year by year in China, and it results in the generation of massive amounts of waste. In China, urban areas are highly correlated with municipal solid waste generation. Municipal solid waste management in China is increasingly shifting towards incineration. Increasing reliance on incineration as a quick disposal option reduces mass and volume considerably, but it generates incineration fly ash. The threat posed by the hazardous content (heavy metals) in improperly handled fly ash is due to the lack of technical and economical feasibility of disposal. However, fly ash can serve as an alternative to natural resources used in cement, ceramics, embankments, road construction, etc. To achieve a safe disposal and reuse of fly ash, cost-effective resource recovery and reuse technologies need to be implemented. The treatment techniques mostly used are thermal treatment, solidification/stabilization and separation techniques. The thermal treatment and solidification/stabilization can be found at full scale (industrial, pilot and lab scales), whereas separation techniques fit in pretreatment. Based on the review of recent literature, it can be concluded that 
thermochemical treatment with the involvement of chlorinating agents can remove maximum amounts of heavy metals from fly ash. The solidification/stabilization method is also capable of fixing the heavy metal in fly ash, but the solidification/stabilization effect is poor under acidic conditions or after a long period of aging. The separation method can selectively recover heavy metal, but a large amount of contaminated wastewater is generated after the treatment, which increases the difficulty of subsequent harmless disposal. This method is still on a laboratory scale, and further research is required. Therefore, it is necessary to comprehensively consider the advantages and disadvantages of different treatment methods and to identify appropriate methods to achieve a harmless disposal of MSWI fly ash. In order to avoid the landfilling of fly ash, potential applications for the utilization of treated fly ash need to be supported by the government and private sectors. The stringent legislations and defiance monitoring are compulsory to manage and reduce the occurrence of heavy metal abundance caused by mismanagement prior to incineration and after the improper disposal.

Author Contributions: F.W., S.C. and A.H.K. conceived and presented the idea. A.H.K. gathered the literature and drafted it. F.W. provided a critical revision of the article and finally approved the final version for publication. All authors contributed equally to finalize the review article. All authors have read and agreed to the published version of the manuscript.

Funding: This research received no external funding.

Acknowledgments: This study was funded and supported by the National Key R\&D Program of China (No.2019YFC1907000), the Science and Technology Plan Project of Zhejiang Province (No. 2018C03041, 2018C03007), and the Key Project of Innovation of Science and Technology of Ningbo City (No. 2018B10023).

Conflicts of Interest: The authors declare no conflict of interest.

\section{References}

1. Kaza, S.; Yao, L.C.; Bhada-Tata, P.; Van Woerden, F. What a Waste 2.0: A Global Snapshot of Solid Waste Management to 2050; Urban Development; World Bank: Washington, DC, USA, 2018.

2. Jing, Z.; Fan, X.; Zhou, L.; Fan, J.; Zhang, Y.; Pan, X.; Ishida, E.H. Hydrothermal Solidification Behavior of Municipal Solid Waste Incineration Bottom Ash without Any Additives. Waste Manag. 2013, 33, 1182-1189. [CrossRef] [PubMed]

3. Shareefdeen, Z.M.; Elkamel, A.; Tse, S. Review of Current Technologies Used in Municipal Solid Waste-to-Energy Facilities in Canada. Clean Technol. Environ. Policy 2015, 17, 1837-1846. [CrossRef]

4. Seo, Y.J. Current MSW Management and Waste-to-Energy Status in the Republic of Korea; Columbia University: New York, NY, USA, 2013.

5. Bureau, E.I. Reference Document on the Best Available Techniques for Waste Incineration; EU: Brussels, Belgium, 2005.

6. Mao, G.; Zhang, Y. Analysis of municipal solid waste treatment status and the feasibility of incineration in China. Urban Dev. Res. 2010, 17, 12-16.

7. Allegrini, E.; Vadenbo, C.; Boldrin, A.; Astrup, T.F. Life cycle assessment of resource recovery from municipal solid waste incineration bottom ash. J. Environ. Manag. 2015, 151, 132-143. [CrossRef]

8. Wiles, C.C. Municipal solid waste combustion ash: State-of-the-knowledge. J. Hazard. Mater. 1996, 47, $325-344$. [CrossRef]

9. Yao, Q.; Samad, N.B.; Keller, B.; Seah, X.S.; Huang, L.; Lau, R. Mobility of heavy metals and rare earth elements in incineration bottom ash through particle size reduction. Chem. Eng. Sci. 2014, 118, 214-220. [CrossRef]

10. Wang, P.; Hu, Y.; Cheng, H. Municipal solid waste (MSW) incineration fly ash as an important source of heavy metal pollution in China. Environ. Pollut. 2019, 252, 461-475. [CrossRef]

11. Zou, D.; Chi, Y.; Fu, C.; Dong, J.; Wang, F.; Ni, M. Co-destruction of organic pollutants in municipal solid waste leachate and dioxins in fly ash under supercritical water using $\mathrm{H} 2 \mathrm{O} 2$ as oxidant. J. Hazard. Mater. 2013, 248, 177-184. [CrossRef]

12. Chen, X.D.; Geng, Y.; Fujita, T. An overview of municipal solid waste management in China. Waste Manag. 2010, 30, 716-724. [CrossRef]

13. Xu, L.; Yan, Z.; Cui, S. Path analysis of influencing factors on municipal solid waste generation: A case study of Xiamen City. Acta Sci. Circ. 2013, 33, 1180-1185. 
14. Zhao, Y.; Ge, X.; Li, X. Factors influencing municipal solid waste generation. Stat. Decis. 2016, 23, 91-94.

15. Zhao, Y.; Christensen, T.H.; Lu, W.; Wu, H.; Wang, H. Environmental Impact Assessment of Solid Waste Management in Beijing City, China. Waste Manag. 2011, 31, 793-799. [CrossRef] [PubMed]

16. Phua, Z.; Giannis, A.; Dong, Z.L.; Lisak, G.; Ng, W.J. Characteristics of incineration ash for sustainable treatment and utilization. Environ. Sci. Pollut. Res. 2019, 26, 16974-16997. [CrossRef] [PubMed]

17. Pan, A.; Yu, L.; Yang, Q. Characteristics and Forecasting of Municipal Solid Waste Generation in China. Sustainability 2019, 11, 1433. [CrossRef]

18. Han, H.; Zhang, Z.J. The impact of the policy of municipal solid waste source-separated collection on waste reduction: A case study of China. J. Mater. Cycles Waste Manag. 2017, 19, 382-393. [CrossRef]

19. Song, G.; Sun, Y. Social cost accounting for municipal solid waste incineration in Beijing. China Popul. Resour. Environ. 2017, 27, 17-27.

20. Al-Khatib, I.A.; Kontogianni, S.; Abu Nabaa, H.; Alshami, N.; Al-Sari, M.I. Public perception of hazardousness caused by current trends of municipal solid waste management. Waste Manag. 2015, 36, 323-330. [CrossRef]

21. Margallo, M.; Taddei, M.B.; Hernández-Pellón, A.; Aldaco, R.; Irabien, A. Environmental Sustainability Assessment of the Management of Municipal Solid Waste Incineration Residues: A Review of the Current Situation. Clean Technol. Environ. Policy 2015, 17, 1333-1353. [CrossRef]

22. Lam, C.H.; Ip, A.W.; Barford, J.P.; McKay, G. Use of incineration MSW ash: A review. Sustainability 2010, 2, 1943-1968. [CrossRef]

23. Sabbas, T.; Polettini, A.; Pomi, R.; Astrup, T.; Hjelmar, O.; Mostbauer, P.; Cappai, G.; Magel, G.; Salhofer, S.; Speiser, C.; et al. Management of Municipal Solid Waste Incineration Residues. Waste Manag. 2003, 23, 61-88. [CrossRef]

24. Lindberg, D.; Molin, C.; Hupa, M. Thermal Treatment of Solid Residues from WtE Units: A Review. Waste Manag. 2015, 37, 82-94. [CrossRef] [PubMed]

25. Quina, M.J.; Bordado, J.C.; Quinta-Ferreira, R.M. Treatment and use of air pollution control residues from MSW incineration: An overview. Waste Manag. 2008, 28, 2097-2121. [CrossRef] [PubMed]

26. Van Der Sloot, H.; Kosson, D.; Hjelmar, O. Characteristics, treatment and utilization of residues from municipal waste incineration. Waste Manag. 2001, 21, 753-765. [CrossRef]

27. Lebersorger, S.; Beigl, P. Municipal solid waste generation in municipalities: Quantifying impacts of household structure, commercial waste and domestic fuel. Waste Manag. 2011, 31, 1907-1915. [CrossRef]

28. Seacat, J.D.; Boileau, N.R. Demographic and community-level predictors of recycling behavior: A statewide, assessment. J. Environ. Psychol. 2018, 56, 12-19. [CrossRef]

29. De Feo, G.; De Gisi, S. Domestic separation and collection of municipal solid waste: Opinion and awareness of citizens and workers. Sustainability 2010, 2, 1297-1326. [CrossRef]

30. Vieira, V.H.A.D.M.; Matheus, D.R. The impact of socioeconomic factors on municipal solid waste generation in Sao Paulo, Brazil. Waste Manag. Res. 2018, 36, 79-85. [CrossRef]

31. Prades, M.; Gallardo, A.; Ibàñez, M.V. Factors determining waste generation in Spanish towns and cities. Environ. Monit. Assess. 2015, 187, 4098-4110. [CrossRef]

32. Jamas, T.; Nepal, R. Issues and options in waste management: A social cost-benefit analysis of waste-to-energy in the UK. Resour. Conserv. Recycl. 2010, 54, 1341-1352. [CrossRef]

33. Zhao, X.-G.; Jiang, G.-W.; Li, A.; Li, Y. Technology, Cost, a Performance of Waste-to-Energy Incineration Industry in China. Renew. Sustain. Energy Rev. 2016, 55, 115-130.

34. Zheng, L.; Song, J.; Li, C.; Gao, Y.; Geng, P.; Qu, B.; Lin, L. Preferential Policies Promote Municipal Solid Waste (MSW) to Energy in China: Current Status and Prospects. Renew. Sustain. Energy Rev. 2014, 36, 135-148. [CrossRef]

35. Cao, S.; Lv, Y.; Zheng, H.; Wang, X. Challenges facing China's unbalanced urbanization strategy. Land Use Policy 2014, 39, 412-415. [CrossRef]

36. Shi, D.; Wu, W.-X.; Lu, S.-Y.; Chen, T.; Huang, H.-L.; Chen, Y.-X.; Yan, J.-H. Effect of MSW source-classified collection on the emission of PCDDs/Fs and heavy metals from incineration in China. J. Hazard. Mater. 2008, 153, 685-694. [CrossRef] [PubMed]

37. Xin-gang, Z.; Gui-wu, J.; Ang, L.; Ling, W. Economic analysis of waste-to-energy industry in China. Waste Manag. 2016, 48, 604-618.

38. Yang, N.; Zhang, H.; Chen, M.; Shao, L.-M.; He, P.-J. Greenhouse gas emissions from MSW incineration in China: Impacts of waste characteristics and energy recovery. Waste Manag. 2012, 32, 2552-2560. [CrossRef] 
39. Yong, C. Waste-to-energy in China. In Proceedings of the Expert Group Meeting on Sustainable Application of Waste-to-Energy in Asian Region, Busan, Korea, 22-23 February 2017.

40. East Asia Infrastructure Department of World Bank. Waste Management in China: Issues and Recommendations; The World Bank: Washington, DC, USA, 2005.

41. Zhang, D.; Huang, G.; Xu, Y.; Gong, Q. Waste-to-Energy in China: Key Challenges and Opportunities. Energies 2015, 8, 14182-14196. [CrossRef]

42. MSW Disposal Amount Achieved Negative Growth Firstly in Recent 10 Years. Available online: http: //igongyi.cntv.cn/ (accessed on 26 February 2014).

43. Waste Surrounding of Guangzhou Will Be Relieved through Circular Economy Industry Zone. Available online: http://news.xinhuanet.com/house/gz/ (accessed on 26 February 2014).

44. National Bureau of Statistics of China. China City Statistical Yearbook 2016; China Planning Press: Beijing, China, 2017.

45. Fan, Y.; Fang, C. Circular economy development in China-current situation, evaluation and policy implications. Environ. Impact Assess. Rev. 2020, 84, 106441. [CrossRef]

46. Fujii, M.; Fujita, T.; Chen, X.; Ohnishi, S.; Yamaguchi, N. Smart recycling of organic solid wastes in an environmentally sustainable society. Resour. Conserv. Recycl. 2012, 63, 1-8. [CrossRef]

47. Geng, Y.; Tsuyoshi, F.; Chen, X. Evaluation of innovative municipal solid waste management through urban symbiosis: A case study of Kawasaki. J. Clean. Prod. 2010, 18, 993-1000. [CrossRef]

48. Yu, J.; Williams, E.; Ju, M.; Shao, C. Managing e-waste in China: Policies, pilot projects and alternative approaches. Resour. Conserv. Recycl. 2010, 54, 991-999. [CrossRef]

49. MOC; NDRC; MIIT; MEP; MOHURD; ACFSMC. Ministry of Commerce, National Development and Reform Commission, Ministry of Industry and Information Technology, Ministry of Environmental Protection, Ministry of Housing and Urban-Rural Development, All-China Federation of Supply and Marketing Cooperatives. Opinion on Promoting Transformation and Upgrading in Recyclable Resources Industry. 2016. Available online: http://www.ndrc.gov.cn/zcfb/zcfbgg/201601/t20160128_773250.html (accessed on 10 October 2020). (In Chinese)

50. Li, L.; Pan, D.A.; Li, B.; Wu, Y.; Wang, H.; Gu, Y.; Zuo, T. Patterns and challenges in the copper industry in China. Resour. Conserv. Recycl. 2017, 127, 1-7. [CrossRef]

51. Tan, Q.; Dong, Q.; Liu, L.; Song, Q.; Liang, Y.; Li, J. Potential recycling availability and capacity assessment on typical metals in waste mobile phones: A current research study in China. J. Clean. Prod. 2017, 148, 509-517. [CrossRef]

52. MOC. Notification on Publishing the Third Batch of Pilot Program on Constructing of Recyclable Resources Recycling System. Ministry of Commerce, 2012. Available online: http://www.mofcom.gov.cn. (accessed on 10 October 2020). (In Chinese)

53. MOF; MEP; NDRC; MIIT; GAC; SAT. Measures for the Collection, Use and Management of Waste Electrical and Electronic Equipment Treating Funds. Ministry of Finance, Ministry of Environmental Protection, National Development and Reform Commission, Ministry of Industry and Information Technology, General Administration of Customs, State Administration of Taxation. 2012. Available online: https://www.ndrc.gov.cn/fggz/hjyzy/fzxhjj/index_2.html (accessed on 10 October 2020). (In Chinese)

54. Xiao, S.; Dong, H.; Geng, Y.; Brander, M. An overview of China's recyclable waste recycling and recommendations for integrated solutions. Resour. Conserv. Recycl. 2018, 134, 112-120. [CrossRef]

55. China National Resources Recycling Association. Industry Development Report of Recycled Resources of China, 2015-2016; China Fortune Press: Beijing, China, 2016.

56. Tai, J.; Zhang, W.; Che, Y.; Feng, D. Municipal solid waste source-separated collection in China: A comparative analysis. Waste Manag. 2011, 31, 1673-1682. [CrossRef]

57. Zhuang, Y.; Wu, S.W.; Wang, Y.L.; Wu, W.X.; Chen, Y.X. Source separation of household waste: A case study in China. Waste Manag. 2008, 28, 2022-2030. [CrossRef]

58. Chung, S.S.; Poon, C.S. A comparison of waste-reduction practices and new environmental paradigm of rural and urban Chinese citizens. J. Environ. Manag. 2001, 62, 3-19. [CrossRef]

59. Morrissey, A.J.; Browne, J. Waste management models and their application to sustainable waste management. Waste Manag. 2004, 24, 297-308. Available online: https://pubmed.ncbi.nlm.nih.gov/15016418/ (accessed on 8 October 2020). [CrossRef] 
60. Chung, S.S.; Poon, C.S. A comparison of waste management in Guangzhou and Hong Kong. Resour. Conserv. Recycl. 1998, 22, 203-216. [CrossRef]

61. Zhang, D.; Keat, T.S.; Gersberg, R.M. A comparison of municipal solid waste management in Berlin and Singapore. Waste Manag. 2010, 30, 921-933. [CrossRef]

62. He, P.J.; Zhang, H.; Zhang, C.G.; Lee, D.J. Characteristics of air pollution control residues of MSW incineration plant in Shanghai. J. Hazard. Mater. 2004, 116, 229-237. [CrossRef]

63. Zhou, H.; Meng, A.; Long, Y.; Li, Q.; Zhang, Y. An overview of characteristics of municipal solid waste fuel in China: Physical, chemical composition and heating value. Renew. Sustain. Energy Rev. 2014, 36, 107-122. [CrossRef]

64. Jia, Y.; Wang, Z.; Xia, S. Source analysis and pollution risk assessment of Heavy metals from shanghai domestic waste. Huanjing Weisheng Gong Cheng 2015, 23, 31-34. (In Chinese)

65. Tansel, B. From electronic consumer products to e-wastes: Global outlook, waste quantities, recycling challenges. Environ. Int. 2017, 98, 35-45. [CrossRef] [PubMed]

66. Tian, H.; Gao, J.; Lu, L.; Zhao, D.; Cheng, K.; Qiu, P. Temporal trends and spatial variation characteristics of hazardous air pollutant emission inventory from municipal solid waste incineration in China. Environ. Sci. Technol. 2012, 46, 10364-10371. [CrossRef]

67. De Boom, A.; Degrez, M. Belgian MSWI fly ashes and APC residues: A characterisation study. Waste Manag. 2012, 32, 1163-1170. [CrossRef]

68. Quina, M.J.; Santos, R.C.; Bordado, J.C.; Quinta-Ferreira, R.M. Characterization of air pollution control residues produced in a municipal solid waste incinerator in Portugal. J. Hazard. Mater. 2008, 152, 853-869. [CrossRef]

69. Alba, N.; Gasso, S.; Lacorte, T.; Baldasano, J.M. Characterization of municipal solid waste incineration residues from facilities with different air pollution control systems. Air Waste Manag. 1997, 47, 1170-1179. [CrossRef]

70. Long, Y.; Shen, D.-S.; Wang, H.-T.; Lu, W.-J.; Zhao, Y. Heavy metal source analysis in municipal solid waste (MSW): Case study on Cu and Zn. J. Hazard. Mater. 2011, 186, 1082-1087. [CrossRef]

71. Zhang, H.; He, P.J.; Shao, L.M. Implication of heavy metals distribution for a municipal solid waste management system-A case study in Shanghai. Sci. Total Environ. 2008, 402, 257-267. [CrossRef]

72. Hjelmar, O. Waste management in Denmark. Waste Manag. 1996, 16, 389-394. [CrossRef]

73. Waste and Recycled Materials Use in the Transportation Industry. In National Cooperative Highway Research Program; Transportation Research Board, National Research Council: Washington, DC, USA, 2000.

74. Chang, C.Y.; Wang, C.F.; Mui, D.T.; Cheng, M.T.; Chiang, H.L. Characteristics of elements in waste ashes from a solid waste incinerator in Taiwan. J. Hazard. Mater. 2008, 165, 766-773. [CrossRef] [PubMed]

75. Wu, H.Y.; Ting, Y.P. Metal extraction from municipal solid waste (MSW) incinerator flyash-chemical leaching and fungal bioleaching. Enzyme Microb. Technol. 2006, 38, 839-847. [CrossRef]

76. Hjelmar, O. Disposal strategies for municipal solid waste incineration residues. J. Hazard. Mater. 1996, 47, 345-368. [CrossRef]

77. The Research on the Utilization of MSWI Residues (II); Taiwan Environmental Protection Agency: Taipei, Taiwan, 2004.

78. Forteza, R.; Far, M.; Segui, C.; Cerda, V. Characterization of bottom ash in municipal solid waste incinerators for its use in road base. Waste. Manag. 2004, 24, 899-909. [CrossRef] [PubMed]

79. Pan, Y.; Wu, Z.; Zhou, J.; Zhao, J.; Ruan, X.; Liu, J.; Qian, G. Chemical characteristics and risk assessment of typical municipal solid waste incineration (MSWI) fly ash in China. J. Hazard. Mater. 2013, 261, 269-276. [CrossRef]

80. Wu, K.; Shi, H.; Schutter, G.; Guo, X.; Ye, G. Preparation of alinite cement from municipal solid waste incineration fly ash. Cem. Concr. Compos. 2012, 34, 322-327. [CrossRef]

81. Jung, C.H.; Matsuto, T.; Tanaka, N.; Okada, T. Metal distribution in incineration residues of municipal solid waste (MSW) in Japan. Waste Manag. 2004, 24, 381-391. [CrossRef]

82. Sakai, S.-I.; Hiraoka, M. Municipal solid waste incinerator residue recycling by thermal processes. Waste Manag. 2000, 20, 249-258. [CrossRef]

83. Shim, Y.-S.; Rhee, S.-W.; Lee, W.-K. Comparison of leaching characteristics of heavy metals from bottom ash and fly ashes in Korea and Japan. Waste Manag. 2005, 25, 473-480. [CrossRef] 
84. Bayuseno, A.P.; Schmahl, W.W. Characterizations of MSWI fly ash through mineralogy and water extraction. Resour. Conserv. Recycl. 2011, 55, 524-534. [CrossRef]

85. Alba, N.; Vázquez, E.; Gassó-Domingo, S.; Baldasano, J.M. Stabilization/solidification of MSW incineration residues from facilities with different air pollution control systems. Durability of matrices versus carbonation. Waste Manag. 2001, 21, 313-323. [CrossRef]

86. Chandler, A.J.; Eighmy, T.T.; Hartlén, J.; Hjelmar, O.; Kosson, D.S.; Sawell, S.E.; Van der Sloot, H.A.; Vehlow, J. Municipal Solid Waste Incinerator Residues, Studies in Environmental Science; Elsevier Science: Amsterdam, The Netherlands, 1997; Volume 67.

87. Li, M.; Xiang, J.; Hu, S.; Sun, L.; Li, P.; Sun, X. Characterization of solid residues from municipal solid waste incinerator. Fuel 2004, 83, 1397-1405. [CrossRef]

88. Jing, Z.; Matsuoka, N.; Jin, F.; Hashida, T.; Yamasaki, N. Municipal incineration bottom ash treatment using hydrothermal solidification. Waste Manag. 2004, 27, 287-293. [CrossRef] [PubMed]

89. Xiong, Y.; Takaoka, M.; Sano, A.; Kusakabe, T.; Yang, J.; Shiota, K.; Fujimori, T.; Oshita, K. Distribution and characteristics of heavy metals in a first-generation monofill site for incinerator residue. J. Hazard. Mater. 2019, 373, 763-772. [CrossRef] [PubMed]

90. Song, G.J.; Kim, K.H.; Seo, Y.C.; Kim, S.C. Characterization of ashes from different locations at the MSW incinerator equipped with various air pollution control devices. Waste Manag. 2004, 24, 99-106. [CrossRef]

91. Cossu, R.; Lai, T.; Pivnenko, K. Waste washing pre-treatment of municipal and special waste. J. Hazard. Mater. 2012, 207-208, 65-72. [CrossRef] [PubMed]

92. Wang, L.; Li, R.; Li, Y.L.; Wei, L.H. Release of Soluble Salts and Heavy Metals during the Short-Time Washing Process of MSWI Fly Ash. Adv. Mater. Res. 2012, 518, 3247-3251. [CrossRef]

93. Wilewska-Bien, M.; Lundberg, M.; Steenari, B.M.; Theliander, H. Treatment process for MSW combustion fly ash laboratory and pilot plant experiments. Waste Manag. 2007, 27, 1213-1224. [CrossRef]

94. Boghetich, G.; Liberti, L.; Notarnicola, M.; Palma, M.; Petruzzelli, D. Chloride extraction for quality improvement of municipal solid waste incinerator ash for the concrete industry. Waste Manag. Res. 2005, 23, 57-61. [CrossRef]

95. Chen, W.-S.; Chang, F.-C.; Shen, Y.-H.; Tsai, M.-S.; Ko, C.-H. Removal of Chloride from MSWI Fly Ash. J. Hazard. Mater. 2012, 237-238, 116-120. [CrossRef]

96. Kirby, C.S.; Rimstidt, J.D. Interaction of municipal solid waste ash with water. Environ. Sci. Technol. 1994, 28, 443-451. [CrossRef] [PubMed]

97. Del Toro, M.A.; Calmano, W.; Ecke, H. Wet extraction of heavy metals and chloride from MSWI and straw combustion fly ashes. Waste Manag. 2009, 29, 2494-2499. [CrossRef] [PubMed]

98. Yang, R.; Liao, W.-P.; Wu, P.-H. Basic Characteristics of Leachate Produced by Various Washing Processes for MSWI Ashes in Taiwan. J. Environ. Manag. 2012, 104, 67-76. [CrossRef] [PubMed]

99. Zhu, F.; Takaoka, M.; Oshita, K.; Kitajima, Y.; Inada, Y.; Morisawa, S.; Tsuno, H. Chlorides Behavior in Raw Fly Ash Washing Experiments. J. Hazard. Mater. 2010, 178, 547-552. [CrossRef] [PubMed]

100. Ma, G.X.; Zhang, H.Y. Washing of the Ash from One Shanghai Plant Using Phosphoric Acid. Adv. Mater. Res. 2013, 664, 228-231. [CrossRef]

101. Wang, Y.; Liu, J.; Sun, S. Effects of water washing on volatile characteristics of heavy metals in fly ash from a MSW and sewage sludge co-combustion plant. J. Cent. South Univ. 2014, 45, 1751-1758.

102. Ferreira, C.; Ribeiro, A.B.; Ottosen, L.M. Study of Different Assisting Agents for the Removal of Heavy Metals from MSW Fly Ashes. In Waste Management and the Environment; Elsevier: Cadiz, Spain, 2002.

103. Goldberg, D. Recycling metal from MSW incinerator ash. Recycl. Today 1988, 26, 34-40.

104. Mizutani, S.; Yoshida, T.; Sakai, S.I.; Takatsuki, H. Release of metals from MSW I fly ash and availability in alkali condition. Waste Manag. 1996, 16, 537-544. [CrossRef]

105. Hong, K.J.; Tokunaga, S.; Ishigami, Y.; Kajiuchi, T. Extraction of heavy metals from MSW incinerator fly ash using saponins. Chemosphere 2000, 41, 345-352. [CrossRef]

106. Wang, Q.; Yang, J.; Wu, T. Effects of water-washing pretreatment on bioleaching of heavy metals from municipal solid waste incinerator fly ash. J. Hazard. Mater. 2009, 162, 812-818. [CrossRef]

107. Fedje, K.K.; Ekberg, C.; Skarnemark, G.; Steenari, B.-M. Removal of hazardous metals from MSW flies ash-An evaluation of ash leaching methods. J. Hazard. Mater. 2010, 173, 310-317. [CrossRef] [PubMed] 
108. Okada, T.; Tojo, Y.; Tanaka, N.; Matsuto, T. Recovery of zinc and lead from fly ash from ash-melting and gasification-melting processes of MSW-Comparison and applicability of chemical leaching methods. Waste Manag. 2007, 27, 69-80. [CrossRef] [PubMed]

109. Zhang, Y.; Ma, Z.; Fang, Z.; Qian, Y.; Zhong, P.; Yan, J. Review of harmless treatment of municipal solid waste incineration fly ash. Waste Dispos. Sustain. Energy 2020, 2, 1-25. [CrossRef]

110. Ishigaki, T.; Nakanishi, A.; Tateda, M.; Ike, M.; Fujita, M. Bioleaching of metal from municipal waste incineration fly ash using a mixed culture of sulfur-oxidizing and iron-oxidizing bacteria. Chemosphere 2005, 60, 1087-1094. [CrossRef] [PubMed]

111. Mulligan, C.N.; Mahtab, K.; Gibbs, B.F. Bioleaching of heavy metals from a low-grade mining ore using Aspergillus niger. J. Hazard. Mater. 2004, 110, 7-84. [CrossRef]

112. Xu, T.J.; Ramanathan, T.; Ting, Y.P. Bioleaching of incineration fly ash by Aspergillus niger-precipitation of metallic salt crystals and morphological alteration of the fungus. Biotechnol. Rep. 2014, 3, 8-14. [CrossRef]

113. Krebs, W.; Bachofen, R.; Brandl, H. Growth stimulation of sulfur oxidizing bacteria for optimization of metal leaching efficiency of fly ash from MSW incineration. Hydrometallurgy 2001, 59, 283-290. [CrossRef]

114. Funari, V.; Mäkinen, J.; Salminen, J.; Braga, R.; Dinelli, E.; Revitzer, H. Metal removal from Municipal Solid Waste Incineration fly ash: A comparison between chemical leaching and bioleaching. Waste Manag. 2016, 60, 397-406. [CrossRef]

115. Bühler, A.; Schlumberger, S. Schwermetalle aus der Flugasche zurückgewinnen Saure Flugaschewäsche-FLUWA-Verfahren ein zukunftsweisendes Verfahren in der Abfallverbrennung. In KVA-Rückstände in der Schweiz-Der Rohstoff mit Mehrwert; Federal Office for the Environment (FOEN): Switzerland, 2010; pp. 185-192.

116. Weibel, G.; Eggenberger, U.; Kulik, D.A.; Hummel, W.; Schlumberger, S.; Klink, W.; Fisch, M.; Mäder, U.K. Extraction of heavy metals from MSWI fly ash using hydrochloric acid and sodium chloride solution. Waste Manag. 2018, 76, 457-471. [CrossRef]

117. Weibel, G. Optimized Metal Recovery from Fly Ash from Municipal Solid Waste Incineration. Ph.D. Thesis, Institute for Geological Sciences, University of Bern, Bern, Switzerland, 2017.

118. Quina, M.J.; Bontempi, E.; Bogush, A.; Schlumberger, S.; Weibel, G.; Braga, R.; Funari, V.; Hyks, J.; Rasmussen, E.; Lederer, J. Technologies for the management of MSW incineration ashes from gas cleaning: New perspectives on recovery of secondary raw materials and circular economy. Sci. Total Environ. 2018, 635, 526-542. [CrossRef]

119. Ottosen, L.M.; Jensen, P.E.; Kirkelund, G.M. Phosphorous Recovery from Sewage Sludge Ash Suspended in Water in a Two-Compartment Electrodialytic Cell. Waste Manag. 2016, 51, 142-148. [CrossRef] [PubMed]

120. Ebbers, B.; Ottosen, L.M.; Jensen, P.E. Comparison of two different electrodialytic cells for separation of phosphorus and heavy metals from sewage sludge ash. Chemosphere 2015, 125, 122-129. [CrossRef] [PubMed]

121. Ebbers, B.; Ottosen, L.M.; Jensen, P.E. Electrodialytic treatment of municipal wastewater and sludge for the removal of heavy metals and recovery of phosphorus. Electrochim. Acta 2015, 181, 90-99. [CrossRef]

122. Guedes, P.; Couto, N.; Ottosen, L.M.; Ribeiro, A.B. Phosphorus recovery from sewage sludge ash through an electrodialytic process. Waste Manag. 2014, 34, 886-892. [CrossRef]

123. Ferreira, C.D.; Jensen, P.; Ottosen, L.; Ribeiro, A. Preliminary treatment of MSW fly ash as a way of improving electrodialytic remediation. J. Environ. Sci. Health Part A Toxic Hazard. Subst. Environ. Eng. 2008, 43, 837-843. [CrossRef]

124. Wills, B.A.; Finch, J. Wills' Mineral Processing Technology (Eighth Edition); Butterworth-Heinemann: Oxford, UK, 2016. [CrossRef]

125. Shen, H.; Forssberg, E. An overview of recovery of metals from slags. Waste Manag. 2003, 23, 933-949. [CrossRef]

126. De Boom, A.; Degrez, M.; Hubaux, P.; Lucion, C. MSWI boiler fly ashes: Magnetic separation for material recovery. Waste Manag. 2011, 31, 1505-1513. [CrossRef]

127. Carre, D.; Templier, J.-C. Removal of Heavy Metals from Fly Ash and Fume Purification Residues Resulting from Waste Incineration. Patent No. FR2716392, 1995. Available online: http://www.patentbuddy.com/ Patent/FR-2716392-B1?ft=true (accessed on 10 October 2020).

128. Kazuo, N. Method for Sorting/Recovering Metallic Compounds from Incineration Ash. Patent No. JP2005074349, 2005. Available online: http://www.patentbuddy.com/Patent/JP-2005074349-A?ft=true\& sr=true (accessed on 10 October 2020). 
129. Xia, Y.; He, P.; Shao, L.; Zhang, H. Metal distribution characteristic of MSWI bottom ash in view of metal recovery. J. Environ. Sci. 2016, 52, 1-12. [CrossRef]

130. Le Forestier, L.; Libourel, G. Characterization of flue gas residues from municipal solid waste combustors. Environ. Sci. Technol. 1998, 32, 2250-2256. [CrossRef]

131. Šyca, M.; Simon, F.G.; Hykš, J.; Braga, R.; Biganzoli, L.; Costa, G.; Funari, V.; Grosso, M. Metal recovery from incineration bottom ash: State-of-the-art and recent developments. J. Hazard. Mater. 2020, 393, 122433. [CrossRef]

132. Smith, Y.R.; Nagel, J.R.; Rajamani, R.K. Eddy current separation for recovery of non-ferrous metallic particles: A comprehensive review. Miner. Eng. 2019, 133, 149-159. [CrossRef]

133. Fraunholcz, N.; Rem, P.C.; Haeser, P. Dry Magnus separation. Miner. Eng. 2002, 15, 45-51. [CrossRef]

134. Zhang, S.; Forssberg, E.; Arvidson, B.; Moss, W. Separation mechanisms and criteria of a rotating eddy-current separator operation. Resour. Conserv. Recycl. 1999, 25, 215-232. [CrossRef]

135. Settimo, F.; Bevilacqua, P.; Rem, P. Eddy current separation of fine non-ferrous particles from bulk streams. Phys. Sep. Sci. Eng. 2004, 13, 15-23. [CrossRef]

136. Schloemann, E.; Reiner, M. Nonferrous metal separators for small particles. IEEE Trans. Magn. 1979, 15, 1535-1537. [CrossRef]

137. Schlömann, E. Separation of nonmagnetic metals from solid waste by permanent magnets I. Theory J. Appl. Phys. 1975, 46, 5012-5021. [CrossRef]

138. Wang, D.; Ma, X.; Zhi, X.; Zhang, S. Research review of scrap metals eddy current separation technology. Sens. Transducers 2013, 158, 242-248.

139. Ruan, J.-J.; Qian, Y.M.; Xu, Z.M. Environment-friendly technology for recovering nonferrous metals from e-waste: Eddy current separation. Resour. Conserv. Recycl. 2014, 87, 109-116.

140. Zhang, J.; Liu, J.; Li, C.; Jin, Y.; Nie, Y.; Li, J. Comparison of the fixation effects of heavy metals by cement rotary kiln co-processing and cement based solidification/stabilization. J. Hazard. Mater. 2009, 165, 1179-1185. [CrossRef]

141. Valls, S.; Vàzquez, E. Leaching properties of stabilised/solidified cement-admixtures-sewage sludges systems. Waste Manag. 2002, 22, 37-45. [CrossRef]

142. Conner, J.R.; Hoeffner, S.L. A critical review of stabilization/solidification technology. Crit. Rev. Environ. Control. 1998, 28, 397-462. [CrossRef]

143. Li, X.; Chen, Q.; Zhou, Y.; Tyrer, M.; Yu, Y. Stabilization of heavy metals in MSWI fly ash using silica fume. Waste Manag. 2014, 3412, 2494-2504. [CrossRef] [PubMed]

144. Van Gerven, T.; Van Baelen, D.; Dutré, V.; Vandecasteele, C. Influence of carbonation and carbonation methods on leaching of metals from mortars. Cem. Concr. Res. 2004, 34, 149-156. [CrossRef]

145. Zha, X.; Ning, J.; Saafi, M.; Dong, L.; Dassekpo, J.-B.M.; Ye, J. Effect of supercritical carbonation on the strength and heavy metal retention of cement-solidified fly ash. Cem. Concr. Res. 2019, 120, 36-45. [CrossRef]

146. Zha, X.; Wang, H.; Xie, P.; Wang, C.; Dangla, P.; Ye, J. Leaching resistance of hazardous waste cement solidification after accelerated carbonation. Cem. Concr. Compos. 2016, 72, 125-132. [CrossRef]

147. Du, W.; Zhang, C.-Y.; Kong, X.-M.; Zhuo, Y.-Q.; Zhu, Z.-W. Mercury release from fly ashes and hydrated fly ash cement pastes. Atmos. Environ. 2018, 178, 11-18. [CrossRef]

148. Derie, R. A new way to stabilize fly ash from municipal incinerators. Waste Manag. 1996, 16, $711-716$. [CrossRef]

149. Mangialardi, T.; Paolini, A.E.; Polettini, A.; Sirini, P. Optimization of the solidification/stabilization process of MSW fly ash in cementitious matrices. J. Hazard. Mater. 1999, 70, 53-70. [CrossRef]

150. Wang, L.; Jin, Y.; Nie, Y. Investigation of accelerated and natural carbonation of MSWI fly ash with a high content of Ca. J. Hazard. Mater. 2010, 174, 334-343. [CrossRef]

151. Haiying, Z.; Youcai, Z.; Jingyu, Q. Thermal characterization of fly ash from one municipal solid waste incinerator (MSWI) in Shanghai. Process. Saf. Environ. Prot. 2010, 88, 269-275. [CrossRef]

152. Wey, M.-Y.; Liu, K.-Y.; Tsai, T.-H.; Chou, J.-T. Thermal treatment of the fly ash from municipal solid waste incinerator with rotary kiln. J. Hazard. Mater. 2006, 137, 981-989. [CrossRef] [PubMed]

153. Polettini, A.; Pomi, R.; Trinci, L.; Muntoni, A.; Mastro, S.L. Engineering and environmental properties of thermally treated mixtures containing MSWI fly ash and low-cost additives. Chemosphere 2004, 56, 901-910. [CrossRef] [PubMed] 
154. Cheeseman, C.; Da Rocha, S.M.; Sollars, C.; Bethanis, S.; Boccaccini, A. Ceramic processing of incinerator bottom ash. Waste Manag. Amst. Neth. 2003, 23, 907-916. [CrossRef]

155. Mangialardi, T. Sintering of MSW fly ash for reuse as a concrete aggregate. J. Hazard. Mater. 2001, 87, $225-239$. [CrossRef]

156. Wang, K.S.; Sun, C.J.; Liu, C.Y. Effects of the type of sintering atmosphere on the chromium leachability of thermal-treated municipal solid waste incinerator fly ash. Waste Manag. Oxf. 2000, 21, 85-91. [CrossRef]

157. Li, R.; Li, Y.; Yang, T.; Wang, L.; Wang, W. A new integrated evaluation method of heavy metals pollution control during melting and sintering of MSWI fly ash. J. Hazard. Mater. 2015, 289, 197-203. [CrossRef]

158. Chou, S.Y.; Lo, S.L.; Hsieh, C.H.; Chen, C.L. Sintering of MSWI fly ash by microwave energy. J. Hazard. Mater. 2009, 163, 357-362. [CrossRef]

159. Wang, Q.; Tian, S.; Wang, Q.; Huang, Q.; Yang, J. Melting characteristics during the vitrification of MSWI fly ash with a pilot-scale diesel oil furnace. J. Hazard. Mater. 2008, 160, 376-381. [CrossRef]

160. Bethanis, S.; Cheeseman, C.R.; Sollars, C.J. Properties and microstructure of sintered incinerator bottom ash. Ceram. Int. 2002, 28, 881-886. [CrossRef]

161. Wang, K.-S.; Chiang, K.-Y.; Perng, J.-K.; Sun, C.-J. The characteristics study on sintering of municipal solid waste incinerator ashes. J. Hazard. Mater. 1998, 59, 201-210. [CrossRef]

162. Sørensen, M.; Mogensen, E.; Lundtorp, K.; Jensen, D.; Christensen, T. High temperature co-treatment of bottom ash and stabilized fly ashes from waste incineration. Waste Manag. 2001, 21, 555-562. [CrossRef]

163. De Casa, G.; Mangialardi, T.; Paolini, A.; Piga, L. Physical-mechanical and environmental properties of sintered municipal incinerator fly ash. Waste Manag. Amst. Neth. 2006, 27, 238-247. [CrossRef] [PubMed]

164. Boccaccini, A.R.; Schawohl, J.; Kern, H.; Schunck, B.; Rincon, J.M.; Romero, M. Sintered glass ceramics from municipal incinerator fly ash. Glass Technol. 2000, 41, 99-105.

165. Tian, S.; Li, J.; Liu, F.; Guan, J.; Dong, L.; Wang, Q. Behavior of Heavy Metals in the Vitrification of MSWI Fly Ash with a Pilot-scale Diesel Oil Furnace. Procedia Environ. Sci. 2012, 16, 214-221. [CrossRef]

166. Wang, X.; Jin, B.; Xu, B.; Lan, W.; Qu, C. Melting characteristics during the vitrification of MSW incinerator fly ash by swirling melting treatment. J. Mater. Cycles Waste Manag. 2017, 19, 483-495. [CrossRef]

167. Okada, T.; Tomikawa, H. Leaching characteristics of lead from melting furnace fly ash generated by melting of incineration fly ash. J. Environ. Manag. 2012, 110, 207-214. [CrossRef]

168. Yue, Y.; Zhang, J.; Sun, F.; Wu, S.; Pan, Y.; Zhou, J.; Qian, G. Heavy metal leaching and distribution in glass products from the co-melting treatment of electroplating sludge and MSWI fly ash. J. Environ. Manag. 2019, 232, 226-235. [CrossRef]

169. Zhao, P.; Ni, G.; Jiang, Y.; Chen, L.; Chen, M.; Meng, Y. Destruction of inorganic municipal solid waste incinerator fly ash in a DC arc plasma furnace. J. Hazard. Mater. 2010, 181, 580-585. [CrossRef]

170. Wang, Q.; Yan, J.-H.; Chi, Y.; Li, X.-D.; Lu, S. Application of thermal plasma to vitrify fly ash from municipal solid waste incinerators. Chemosphere 2010, 78, 626-630. [CrossRef]

171. Ma, W.; Fang, Y.; Chen, D.; Chen, G.; Xu, Y.; Sheng, H.; Zhou, Z. Volatilization and leaching behavior of heavy metals in MSW incineration fly ash in a DC arc plasma furnace. Fuel 2017, 210, 145-153. [CrossRef]

172. Károly, Z.; Mohai, I.; Toth, M.; Weber, F.; Szépvölgyi, J. Production of glass ceramics from fly ash using arc plasma. J. Eur. Ceram. Soc. 2007, 27, 1721-1725. [CrossRef]

173. Čarnogurská, M.; Lázár, M.; Puškár, M.; Lengyelová, M.; Václav, J.; Širillová, L. Measurement and evaluation of properties of MSW fly ash treated by plasma. Measurement 2015, 62, 155-161. [CrossRef]

174. Fraißler, G.; Jöller, M.; Brunner, T.; Obernberger, I. Influence of dry and humid atmosphere on the thermal decomposition of calcium chloride and its impact on the remove of heavy metals by chlorination. Chem. Eng. Process. 2009, 48, 380-388. [CrossRef]

175. Nowak, B.; Rocha, S.F.; Aschenbrenner, P.; Rechberger, H.; Winter, F. Heavy metal removal from MSW fly ash by means of chlorination and thermal treatment: Influence of the chloride type. Chem. Eng. J. 2012, 179, 178-185. [CrossRef]

176. Liu, J.-Y.; Sun, S. Chlorination transformation and volatilization of heavy metals in fly ash from the incineration during the disposal process with higher temperature. Chin. J. Environ. Sci. 2012, 33, 3279-3287.

177. Li, R.; Zhao, W.; Li, Y.; Wang, W.; Zhu, X. Heavy metal removal and speciation transformation through the calcination treatment of phosphorus-enriched sewage sludge ash. J. Hazard. Mater. 2015, 283, 423-431. [CrossRef] 
178. Chan, C.; Jia, C.Q.; Graydon, J.W.; Kirk, D.W. The behaviour of selected heavy metals in msw incineration electrostatic precipitator ash during roasting with chlorination agents. J. Hazard. Mater. 1996, 50, 1-13. [CrossRef]

179. Nowak, B.; Pessl, A.; Aschenbrenner, P.; Szentannai, P.; Mattenberger, H.; Rechberger, H.; Hermann, L.; Winter, F. Heavy metal removal from municipal solid waste fly ash by chlorination and thermal treatment. J. Hazard. Mater. 2010, 179, 323-331. [CrossRef]

180. Nowak, B.; Perutka, L.; Aschenbrenner, P.; Kraus, P.; Rechberger, H.; Winter, F. Limitations for heavy metal release during thermo-chemical treatment of sewage sludge ash. Waste Manag. 2011, 31, 1285-1291. [CrossRef]

181. Nowak, B.; Aschenbrenner, P.; Winter, F. Heavy metal removal from sewage sludge ash and municipal solid waste fly ash-A comparison. Fuel Process. Technol. 2013, 105, 195-201. [CrossRef]

182. Vogel, C.; Adam, C. Heavy metal removal from sewage sludge ash by thermochemical treatment with gaseous hydrochloric acid. Environ. Sci. Technol. 2011, 45, 7445-7450. [CrossRef] [PubMed]

183. Struis, R.P.W.J.; Ludwig, C.; Lutz, H.; Scheidegger, A.M. Speciation of zinc in municipal solid waste incineration fly ash after heat treatment: An X-ray absorption spectroscopy study. Environ. Sci. Technol. 2004, 38, 3760-3767. [CrossRef] [PubMed]

184. Fraissler, G.; Jöller, M.; Mattenberger, H.; Brunner, T.; Obernberger, I. Thermodynamic equilibrium calculations concerning the removal of heavy metals from sewage sludge ash by chlorination. Chem. Eng. Process. Process. Intensif. 2009, 48, 152-164. [CrossRef]

185. Mattenberger, H.; Fraißler, G.; Brunner, T.; Herk, P.; Hermann, L.; Obernberger, I. Sewage sludge ash to phosphorus fertilizer: Variables influencing heavy metal removal during thermochemical treatment. Waste Manag. 2008, 28, 2709-2722. [CrossRef]

186. Mattenberger, H.; Fraissler, G.; Jöller, M.; Brunner, T.; Obernberger, I.; Herk, P.; Hermann, L. Sewage sludge ash to phosphorus fertiliser (II): Influences of ash and granulate type on heavy metal removal. Waste Manag. 2010, 30, 1622-1633. [CrossRef]

187. Yu, J.; Sun, L.; Ma, C.; Qiao, Y.; Xiang, J.; Hu, S.; Yao, H. Mechanism on heavy metals vaporization from municipal solid waste fly ash by MgCl2_6H2O. Waste Manag. 2016, 49, 124-130. [CrossRef]

188. Saikia, N.; Kato, S.; Kojima, T. Production of cement clinkers from municipal solid waste incineration (MSWI) fly ash. Waste Manag. 2007, 27, 1178-1189. [CrossRef]

189. Murat, M.; Sorrentino, F. Effect of large additions of $\mathrm{Cd}, \mathrm{Pb}, \mathrm{Cr}, \mathrm{Zn}$, to cement raw meal on the composition and the properties of the clinker and the cement. Cem. Concr. Res. 1996, 26, 377-385. [CrossRef]

190. Stephan, D.; Mallmann, R.; Knfel, D.; Hrdtl, R. High intakes of Cr, Ni, and Zn in clinker Part, I. Influence on burning process and formation of phases. Cem. Concr. Res. 1999, 29, 1949-1957. [CrossRef]

191. Kakali, G.; Parissakis, G. Investigation of the effect of $\mathrm{Zn}$ oxide on the formation of Portland cement clinker. Cem. Concr. Res. 1995, 25, 79-85. [CrossRef]

192. Pera, J.; Coutaz, L.; Ambroise, J.; Chababbet, M. Use of incinerator bottom ash in concrete. Cem. Concr. Res. 1997, 27, 1-5. [CrossRef]

193. Cinquepalmi, M.A.; Mangialardi, T.; Panei, L.; Paolini, A.E.; Piga, L. Reuse of cement-solidified municipal incinerator fly ash in cement mortars: Physico-mechanical and leaching characteristics. J. Hazard. Mater. 2008, 151, 585-593. [CrossRef] [PubMed]

194. Queralt, I.; Querol, X.; López-Soler, A.; Plana, F. Use of coal fly ash for ceramics: A case study for a large Spanish power station. Fuel 1997, 76, 787-791. [CrossRef]

195. Rokhvarger, A.E. Environmental and waste management issues in the ceramic industry II. In Ceramic Transactions; Bickford, D., Bates, S., Jain, V., Smith, G., Eds.; The American Ceramic Society: Westerville, OH, USA, 1994; Volume 45, pp. 125-135. Available online: https:/www.amazon.com/EnvironmentalManagement-Ceramic-Industry-Transactions/dp/0944904793 (accessed on 20 October 2020).

196. Arm, M. Variation in deformation properties of processed MSWI bottom ash: Results from triaxial tests. Waste Manag. 2004, 24, 1035-1042. [CrossRef]

197. Abdulahi, M. Municipal solid waste incineration bottom ash as road construction material. AU J. Technol. 2009, 13, 121-128.

198. Dabo, D.; Badreddine, R.; De Windt, L.; Drouadaine, I. Ten-years chemical evolution of leachate and municipal solid waste incineration bottom ash used in a test road site. J. Hazard. Mater. 2009, 172, 904-913. [CrossRef] 
199. Lidelöw, S.; Lagerkvist, A. Evaluation of leachate emissions from crushed rock and municipal solid waste incineration bottom ash used in road construction. Waste Manag. 2007, 27, 1356-1365. [CrossRef]

200. Lind, B.-B.; Norrman, J.; Larsson, L.B.; Ohlsson, S.-Å.; Bristav, H. Geochemical anomalies from bottom ash in a road construction-Comparison of the leaching potential between an ash road and the surroundings. Waste Manag. 2008, 28, 170-180. [CrossRef]

201. Mizutani, S.; Sakai, S.I.; Takatsuki, H. Leaching behaviors of heavy metals from MSWI residues and $\mathrm{Pb}$ adsorption onto the residues under alkaline conditions. Waste Manag. Ser. 2000, 1, 726-732.

202. Meima, J.A.; Comans, R.N. The leaching of trace elements from municipal solid waste incinerator bottom ash at different stages of weathering. Appl. Geochem. 1999, 14, 159-171. [CrossRef]

203. Tay, J.; Goh, A.T.C. Engineering properties of incinerator residue. J. Environ. Eng. 1991, 117, $224-235$. [CrossRef]

204. Tay, J.; Goh, A.T.C. Municipal solid-waste incinerator fly ash for geotechnical applications. J. Geotech. Eng. 1993, 119, 811-825.

205. Mulder, E. Pre-Treatment of MSWI fly ash for useful application. Waste Manag. 1996, 16, 181-184. [CrossRef]

206. Gandhimathi, R.; Ramesh, S.T.; Sindhu, V.; Nidheesh, P.V. Single and tertiary system dye removal from aqueous solution using bottom ash: Kinetic and isotherm studies. Iran. J. Energy Environ. 2012, 3, $35-45$. [CrossRef]

207. Gupta, V.K.; Ali, I.; Saini, V.K.; Van Gerven, T.; Van Der Bruggen, B.; Vandecasteele, C. Removal of dyes from wastewater using bottom ash. Ind. Eng. Chem. Res. 2005, 44, 3655-3664. [CrossRef]

208. Monash, P.; Pugazhenthi, G. Adsorption of crystal violet dye from aqueous solution using mesoporous materials synthesized at room temperature. Adsorption 2009, 15, 390-405. [CrossRef]

209. Yang, G.C.C.; Yang, T.Y. Synthesis of zeolites from municipal incinerator fly ash. J. Hazard. Mater. 1998, 62, 75-89. [CrossRef]

210. Miyake, M.; Tamura, C.; Matsuda, M. Resource recovery of waste incineration fly ash: Synthesis of zeolites A and P. J. Am. Ceram. Soc. 2002, 85, 1873-1875. [CrossRef]

211. Chiang, Y.W.; Ghyselbrecht, K.; Santos, R.M.; Meesschaert, B.; Martens, J.A. Synthesis of zeolitic-type adsorbent material from municipal solid waste incinerator bottom ash and its application in heavy metal adsorption. Catal. Today 2012, 190, 23-30. [CrossRef]

212. Xue, Q.; Li, J.-S.; Wang, P.; Liu, L.; Li, Z.-Z. Removal of heavy metals from landfill leachate using municipal solid waste incineration fly ash as adsorbent. CLEAN Soil Air Water 1999, 41, 1-6. [CrossRef]

213. Rosen, C.J.; Olson, D.; Bierman, P.M. Swiss Chard and Alfalfa Responses to Soils Amended with Municipal Solid Waste Incinerator Ash: Growth and Elemental Composition. J. Agric. Food Chem. 1994, 42, 1361-1368. [CrossRef]

214. Giordano, P.M.; Behel, A.D.; Lawrence, J.E.; Soileau, J.M.; Bradford, B.N. Mobility in Soil and Plant Availability of Metals Derived from Incinerated Municipal Refuse. Environ. Sci. Technol. 1983, 17, 193. [CrossRef] [PubMed]

215. Ferreira, J.C.; Strcht, A.; Ribeiro, J.R.; Soeirp, A.; Cotrim, G. Manual de Agricultura Biológica—Fertilização e Proteç̧ão das Plantas Para uma Agricultura Sustentável, 2nd ed.; Associação Portuguesa de Agricultura Biológica: Lisboa, Portugal, 1999.

216. Hwa, T.J.; Jeyaseelan, S. Conditioning of oily sludges with municipal solid wastes incinerator fly ash. Water Sci. Technol. 1997, 35, 231-238. [CrossRef]

Publisher's Note: MDPI stays neutral with regard to jurisdictional claims in published maps and institutional affiliations.

(C) 2020 by the authors. Licensee MDPI, Basel, Switzerland. This article is an open access article distributed under the terms and conditions of the Creative Commons Attribution (CC BY) license (http://creativecommons.org/licenses/by/4.0/). 